Article

\title{
House Prices, Mortgage Rate, and Policy: Megadata Analysis in Taipei
}

\author{
Chien-Ming $\mathrm{Yu}^{1}$ and Pei-Fen Chen ${ }^{2, *}$ \\ 1 Department of International Business Studies, National Chi-Nan University, No.470 Daxue Rd., \\ Puli Township, Nantou County 54561, Taiwan; s101212906@mail1.ncnu.edu.tw \\ 2 Institute of China and Asia-Pacific Studies, National Sun Yat-Sen University, No.70, Lianhai Rd., \\ Gushan Dist., Kaohsiung City 80424, Taiwan \\ * Correspondence: pfchen@mail.nsysu.edu.tw
}

Received: 18 February 2018; Accepted: 19 March 2018; Published: 22 March 2018

check for updates

\begin{abstract}
There are intensive concerns about the causes of rising housing prices in Taipei. The aims of this study are twofold. The first addresses the issue of whether the low-interest-rate policy is adversely driving housing prices in the metropolitan area of Taipei. The second is to investigate if two important housing policies, luxury tax and actual price registration, help to depress the rising residential house prices. With the mega tick data of Taipei city for more than 80,000 residential house transaction records, we examined the factors influencing the actual house prices spanning the period from June 2008 through May 2014. We applied the least squares regression and the quantile regression in the model estimations for housing valuation. In addition, the megadata set is organized in time series and cross-section structures for five subdistricts and the whole Taipei city as well. The empirical results show that low mortgage rates have been the most significant factor for soaring housing prices in Taipei for the past decade. We estimate that a $1 \%$ increase in mortgage rates reduces housing prices from $5 \%$ to $17 \%$. The actual price registration policy contributes to the decrease in housing prices by $4 \%$ to $29 \%$. Housing policy implications are made based on our empirical findings.
\end{abstract}

Keywords: house policy; macroeconomic factor; luxury tax; actual price registration; mortgage rate; tick data

\section{Introduction}

The real estate market in the Taipei metropolitan area has shown an annual increase in recent years that has exceeded a level that the general public can bear in price. In this study we looked at data on more than 80,000 units of residential housing in Taipei City and the price per unit (The unit throughout this article is "Ping". One Ping is equal to $3.3058 \mathrm{~m}^{2}$. The information was provided by various brand agencies, including Sinyi, Yungching, U-trust, Taiwan Realty, H\&B Business, China Trust Real Estates, ETWarm, Chiunsen, Pacific, 21st century, National Realty, Everspring, and the Bank of Taiwan). So, for example, the average price per unit area in January 2009 was roughly 325,100 and it increased to an average of 676,300 by May 2014 , yielding an upsurge of $108 \%$ in five years and an average annual increase of $21.6 \%$, which was significantly higher than the average wage increase. Some people will never be able to save enough for a down payment. If they do, however, the monthly mortgage will simply result in lowering the standard of their daily lives. The policy must prevent short-term speculative purchases that lead to excessive capitalization of the real estate market. Several policies were respectively introduced, namely, the luxury tax in June 2011, the actual pricing registration in August 2012, and the integrated housing and land tax system in January 2016. 
In 2007, the subprime mortgage crisis in the United States heavily impacted the global economy and resulted in financial disaster on a global scale. This study believes that in order to suppress soaring housing prices, it is necessary to reinforce transparency in real estate transactions and increase interest rates. Low interest rates encourage speculators to invest more capital in real estate to further raise housing prices. Therefore, a motive of this study is to analyze the government's real estate policies, real estate characteristics, the overall factors, and the transparency of transactions from various types of housing information in Taipei City. We will also look at their impact on housing prices in order to propose a solution to this staggering problem.

There were two objectives for this study. One was to examine the impact of mortgage rates on housing prices using individual information such as transactions and housing characteristics in the Taipei metropolitan area. This study argues that only the increase in mortgage rates to create a burden would be an effective tool against the rise of housing prices. Another objective was to analyze the impact on housing prices utilizing individual transaction information to review the effect of the government's policies of "luxury tax" and "actual pricing registration" on inhibiting the pricing of noncommercial housing in the Taipei metropolitan area.

There are numerous international studies on the topic of controlling house prices, but most were in disagreement with one another. Zhang, L. and E. Zoli [1] analyzed the rising cost of houses by the International Monetary Fund (IMF, Washington, DC, USA) and proved there is no correlation between housing prices and low interest rates. However, some scholars agreed that interest rates must be adjusted instead. Levin and Pryce [2], from the theoretical analysis of the impact on the flexibility of pricing based on the supply of housing in the UK, concluded that the suppression of housing costs was mostly due to low interest rates. Reichert [3] believed that increased mortgage rates would increase the purchase cost for owners and the financing cost of the investment. He analyzed data in the US from 1975 to 1987 and concluded that there was a negative correlation between interest rates and housing prices, which was also statistically significant. Muellbauer [4] suggested that the central bank regularly investigate the expected fluctuation in housing prices to detect early signs of possible bubbles in the real estate industry.

This article made four major contributions to the literature: (1) information on over 80,000 individual transactions of noncommercial buildings in the Taipei metropolitan area, with the exception of housing prices. The information includes the price per unit area, the building's age, the unit area, and other data. Thus, the study provides the most detailed and the most complete data on a variety of housing characteristics in Taiwan; (2) the impact on housing prices by the luxury tax and actual pricing registration was systematically analyzed. As such, these policies were generally regarded as ways to control housing prices and to provide some insights from abroad; (3) the Taipei metropolitan area was the most representative in the study in order to reflect influential factors for controlling housing prices in Taiwan. It also provides recommendations for the drafting of important policies to regulate real estate in other regions; and (4) primary findings, in terms of suppressing housing prices in the Taipei metropolitan area, are based on observations made in the study. They show that interest rate adjustments, followed by the actual pricing registration, have a considerable impact on suppressing housing prices.

There were some insights and controversies in the central bank and scholars surrounding the issue of adopting lower interest rates or macroprudential policy to suppress high house prices. However, interest rate adjustments in the financial market could affect many areas of business, including the pricing of other assets and the macroeconomics. Thus, it is imperative that we proceed with caution. The house pricing policy is often so interconnected that not a single measure can be effective in changing the situation. Therefore, this study would attempt to use large amounts of individual transaction information to identify the influential factors and propose recommendations for policy-making. The empirical results show that low mortgage rates have been the most significant factor for soaring housing prices in Taipei for the past decade. 
The study used 132,836 actual records of transaction information from June 2008 to May 2014, for a period of three years. After sifting through the documents, there were still 85,169 records of data for purely residential buildings in Taipei City. To the author's knowledge, this study included the largest sample size of the most complete data on variable housing characteristics in Taiwan. Taipei City has a total of 12 administrative regions. According to the classification in 2009 (Chang et al.) [5], residential buildings were grouped by similarity and recategorized as the old city center (including Chungshan, Chungcheng, and Songshan, three administrative districts), new city center (including Sinyi and Daan, two administrative districts), eastern district (including Neihu and Nangang, two administrative districts), northern district (including Shihlin and Beitou, two administrative districts), and southern district (including Wanhua, Wenshan, and Tatung, three administrative districts). Factors for building characteristics were selected from individual transaction information of real estate, and included the average price per unit area, the average age of the building, and the average building type. Factors for macroeconomic characteristics included mortgage burden (\%), rental index, real estate (possible turnover) index (\%), economic growth rate $(\%)$, mortgage rate (\%), inflation rate (\%), and M1B money supply growth rate (\%), with the luxury tax and the actual pricing registration as the virtual variables.

This paper is divided into six sections. The first is the introduction, followed by the literature review in the second section. The third section includes the method and the research design. Data and model illustrations were included in the fourth section. The fifth section and the sixth section contain the empirical analysis and the conclusion, respectively.

\section{Literature Review}

National and international scholars have proposed different views on the influential factors affecting the pricing of real estate. Peng et al. [6] shows that in the study of macroeconomics' impact on the real estate industry, pre-sale housing prices were always correlated with variables such as the money supply, the number of houses available, and the building area. Chang and Liu [7] investigated the real estate quality, the price, and the consumer price index and pointed out many factors affecting the housing market. Lin and Pay [8] used the vector auto regression model to investigate the relationship between housing prices and macroeconomic fluctuation. The study verified that housing prices could indeed fluctuate along with economic change. Wu [9] used the expected appreciation rate for analyzing housing prices and showed that the general public was more susceptible to previous experiences. Li et al. [10] studied price differences in a variety of housing types in the Taipei metropolitan area and pointed out a significant increase in marginal price of quantity premiums in the relationship between area and the price of high-rise apartments and townhouses. Lee et al. [11] studied the key factors for housing prices in Kaohsiung City.

Lin and Ma [12] studied the application of mass appraisal and the Hedonic equation in the real estate market in Taiwan. Chang et al. [13] studied the application of mass appraisal and the quantile regression for improving atypical residential valuation. In terms of accuracy, the method indeed satisfied the expected objective of the research and its estimation was better than the least squares of the hedonic price model.

As for taxation, Shieh [14] analyzed the dynamic impact of local public expenses and taxation on housing prices. The empirical result showed that taxable income had a negative influence on housing prices. Yang [15] analyzed the influence of fiscal policy on housing prices to find that the amount of tax levied would increase the cost of carry (ownership) for investors. The current land value tax and house tax are the cost of carry for investors and the current practice is placing emphasis on more house taxes than land value taxes, with the underlying idea that the tendency to hold on to a property will decrease if the land value taxes were too high. Chang [16] attempted to find the political business cycle in the local government to analyze the correlation between politics and housing prices. The study showed that there was indeed a political business cycle at the local level, which was generally 
accompanied by excessive capitalization in the real estate industry as reflected in the tendency to show relatively higher housing prices.

Summers [17] pointed out that the increase in inflation could result in more demand for real estate and a decline in the stock market. The "Global Financial Stability Report" of the International Monetary Fund (IMF, Washington, DC, USA) [18] suggested that long-term easing of monetary policy could encourage the financial industry to overbear risks, leading to asset appreciation, narrowing of spreads, and a record low volatility, to expand global financial stability risk. Lane [19] indicated a strong correlation among global liquidity, international liability flow, and national credit. Rey [20] found that advanced countries had decided on global liquidity and sometimes could even override their domestic monetary policy (referring to the elasticity of exchange rate). As a result of spillover due to the policies of the core advanced countries, the global interest rate was relatively low and Taiwan was no exception [21]. Taylor [22] and Bernanke [23] believed low interest rates were the cause of a bubble in the real estate industry, which was due to the easing of the monetary policy or the global savings glut. However, it was partially stressed that reducing down payments for the development of real estate and finance was the main driving force for prosperity [24]. Another point of view emphasized the over-optimistic expectation of future housing price [25,26]. Del Giudice V. et al. [26] point out that estimation can be carried out using statistical parametric models (e.g., multiple regression or semiparametric models), which are able to define the market price as a function of the variables corresponding to the property's characteristics, including those relating to the environmental qualification of the territory.

For policies, Peng et al. [27] analyzed the volatility of structural changes in housing prices using data from Taipei City and its county as the example to point out the implementation of monetary policy as an intervention for the monetary policy of the central bank or a sudden event in the future political and economic environment to indirectly prevent the change and stabilize the fluctuation in housing prices. Chen et al. [28] studied the price, the income, and the flexibility of interest rates for housing and suggested that speculative buyers were more sensitive to the flexibility of income. However, the scholars believed that finding reliable information on real estate transactions could prove to be difficult, but the real estate price index could help to resolve the problem and promote efficiency [29].

\section{Method and Research Design}

\subsection{Hedonic Model for Pricing}

Lancaster [30] argued that consumers' purchase of goods was due to the demand of specific commodity characteristics. Rosen [31] further extended it to propose the Hedonic Price Theory, which stated that a product has a composition of multiple features from which its price is determined. The Hedonic equation is generally used with price as a dependent variable and various product features as independent variables. Miller [32] also reviewed the Hedonic price model of residential housing. From studies by Kirby [33], Mark and Goldberg [34], Detweiler and Radigan [35], and Su et al. [36], there were many experiences of using the Hedonic price model in valuation of real estate in different countries. The study variables related to house prices could be divided into three categories, namely, the individual building characteristics (such as area, age, floor, and geographic region), the macroeconomic characteristics, and the housing policy. The study used both the least squares regression and the quantile regression as an estimation model for housing valuation. The data used was both time-series and cross-sectional data. 


\subsection{Quantile Regression}

The least squares regression and the quantile regression were used as an estimation model for housing valuation. The quantile regression was the marginal effect of explanatory variable under a specific quantile of explained variable [37-40]. In previous empirical studies [41-44], when sample distribution was impartial, the result of conditional mean was representative and the estimations of both the least squares regression and the quantile regression were identical. Five quantiles, which were, respectively, $0.1,0.25,0.5,0.75$, and 0.9 , were selected for the quantile regression model.

\subsection{Research Design}

Based on the unit price of actual real estate transactions in each administrative district of Taipei City, the logarithm of monthly average unit price was the explained variable. As for the explanatory variables, they were the building characteristics, the macroeconomic characteristics, and the housing policy. The building characteristics of the first category included the monthly average building area, the monthly average age of the building, and the floor, in which all variables were processed by logarithmic calculation. The second category was the macroeconomic characteristics. In considering that the macroeconomic values were mostly post-event, this study used the values from previous periods to explore their relationships to house prices and these characteristics included the mortgage burden (\%), the rent index, the real estate index (possible turnover, $\%$ ), the economic growth rate $(\%)$, the mortgage rate $(\%)$, the inflation rate $(\%)$, and the M1B money supply growth rate $(\%)$ from previous months. The third category was the housing policy, including the luxury tax and the actual price registration. The implementation of luxury tax was set with value 1 and not 0 while the implementation of registration was set with value 1 and not 0 . Lastly, the least squares regression and the quantile regression were used as an estimation model for housing valuation.

\section{Data and Model Illustration}

\subsection{Research Data}

In terms of data acquisition, according to the International Valuation Standards, market-based valuations are generally grounded on actual transaction information from the market, and price is the overall process of price charged, bidding, or payment of goods and services, which will become clear upon completion of this study. The transaction price reflects the real price of a deal and can reduce possible errors that may occur as a result of the different types of unequal market share. In the investigation of trends in residential demand, it became apparent that the proportion of population purchasing housing through an intermediary agency increased. In fact, such public data of transactions were more representative of the information. Additionally, given the date of the initial implementation of the actual pricing registration for detailing the actual transaction information in real estate in August 2012, information on transactions prior to the time was difficult to obtain. However, since the luxury tax was implemented one year prior to the registry system, to understand the impact of the housing policy and the macroeconomic characteristics on house prices, the transaction communiqués over a period of six years (for a total of 72 months) from June 2008 to May 2014 before and after the start of the luxury tax were collected. The information came from various brand agencies, as well as commissioned land registration agencies, and the Bank of Taiwan and include a total of 132,836 records, as illustrated as descriptive statistics in Table 1. 
Table 1. Empirical sample descriptive statistics.

\begin{tabular}{ccccc}
\hline Variable & Original Samples & Empirical Samples & $\begin{array}{c}\text { Before Luxury Tax } \\
\text { Samples }\end{array}$ & $\begin{array}{c}\text { After Luxury Tax } \\
\text { Samples }\end{array}$ \\
\hline Taipei city & 132,836 & 85,169 & 27,854 & 57,315 \\
\hline Old city center & 36,899 & 25,091 & 6545 & 18,546 \\
\hline Chungshan district & 20,399 & 13,871 & 2872 & 10,999 \\
Chungcheng district & 8272 & 5625 & 1816 & 3809 \\
Songshan district & 8228 & 5595 & 1857 & 7058 \\
\hline New city center & 17,568 & 11,660 & 4602 & 3074 \\
\hline Sinyi district & 7952 & 5121 & 2047 & 3984 \\
Daan district & 9616 & 6539 & 2555 & 10,251 \\
\hline Eastern district & 24,211 & 15,257 & 5006 & 8050 \\
\hline Neihu district & 16,922 & 11,507 & 3457 & 2201 \\
\hline Nangang district & 7289 & 3750 & 1549 & 8589 \\
\hline Northern district & 23,223 & 14,266 & 5677 & 4347 \\
\hline Shihlin district & 11,685 & 7168 & 2821 & 4242 \\
Beitou district & 11,538 & 7098 & 2856 & 12,871 \\
\hline Southern district & 30,935 & 18,895 & 6024 & 3538 \\
\hline Wanhua district & 7828 & 4983 & 1445 & 7306 \\
Wenshan district & 17,853 & 10,700 & 3394 & 2027 \\
Tatung district & 5254 & 3212 & 1185 &
\end{tabular}

Old city center (including Chungshan, Chungcheng, and Songshan, three administrative districts), new city center (including Sinyi and Daan, two administrative districts), eastern district (including Neihu and Nangang, two administrative districts), northern district (including Shihlin and Beitou, two administrative districts) and southern district (including Wanhua, Wenshan, and Tatung, three administrative districts). The period is from June 2008 to May 2014.

To avoid a violation of the Personal Information Protection Act, each unit only provided individual building characteristics, which were complex and in different formats. It took a good deal of manpower and time to repetitively compare data and eliminate incomplete records through multiple screening processes. In the end, residential housing information from Taipei City was used with a total of 85,169 records verified, as seen in Table 1. We express the price of a house in ten thousand Taiwanese dollars (TWD) per unit (Ping). One Ping is equal to $3.3058 \mathrm{~m}^{2}$. As seen in Table 2, the unit price in Taipei City had a maximum of 91.80 , which was seen in the new city center, and the minimum unit price of 26.60 was observed in the southern district. Figure 1 shows the average house transaction unit (ten thousand/per ping) price in each district of Taipei City.

Table 2. Descriptive statistics of housing price in Taipei city and each district.

\begin{tabular}{ccccc}
\hline Variable & Mean & Std. & Min & Max \\
\hline Taipei city & 49.77 & 9.3111 & 32.51 & 67.63 \\
Old city center & 45.75 & 11.0819 & 36.62 & 80.87 \\
New city center & 50.37 & 14.2858 & 43.73 & 91.80 \\
Eastern district & 38.35 & 9.3111 & 29.30 & 62.47 \\
Northern district & 35.68 & 7.5479 & 30.00 & 63.52 \\
Southern district & 27.54 & 7.8537 & 26.60 & 54.78 \\
\hline
\end{tabular}

The house price is presented in ten thousand Taiwanese dollars (TWD) per ping. One "ping" is equal to $3.3058 \mathrm{~m}^{2}$. The period is from June 2008 to May 2014. 
As seen in Table 3, the maximum mortgage burden (\%) was $65.64 \%$ and the minimum was $38.87 \%$. The rent index had a maximum value of 101.96 and a minimum value of 99.43 . The real estate index (possible turnover, \%) maximum was at a value of $139.61 \%$ and the minimum at a value of $88.39 \%$. The maximum and the minimum economic growth rates $(\%)$ were $13.11 \%$ and $-8.12 \%$, respectively. Mortgage rate $(\%)$ ranged from $2.86 \%(\max )$ to $1.62 \%(\mathrm{~min})$. The inflation rate $(\%)$ reached the maximum level at 1.8054, while the minimum was -1.8431 . Data showed the maximum M1B money supply growth rate (\%) at a value of 4.0435 and the minimum at a value of -1.1705 .

Table 3. Descriptive statistics of independent variables.

\begin{tabular}{ccccc}
\hline Variable & Mean & Std. & Min & Max \\
\hline Mortgage burden (\%) & 54.9981 & 8.6819 & 38.87 & 65.64 \\
Rental index (\%) & 100.3366 & 0.7699 & 99.43 & 101.96 \\
Possible turnover index (\%) & 110.8214 & 15.9767 & 88.39 & 139.61 \\
Economic growth rate (\%) & 2.7484 & 5.5298 & -8.12 & 13.11 \\
Mortgage rate (\%) & 1.9368 & 0.2958 & 1.62 & 2.86 \\
Inflation rate (\%) & 0.0969 & 0.7001 & -1.8431 & 1.8054 \\
M1B money supply growth (\%) & 0.7596 & 1.2515 & -1.1705 & 4.0435 \\
\hline
\end{tabular}

The period is from June 2008 to May 2014.

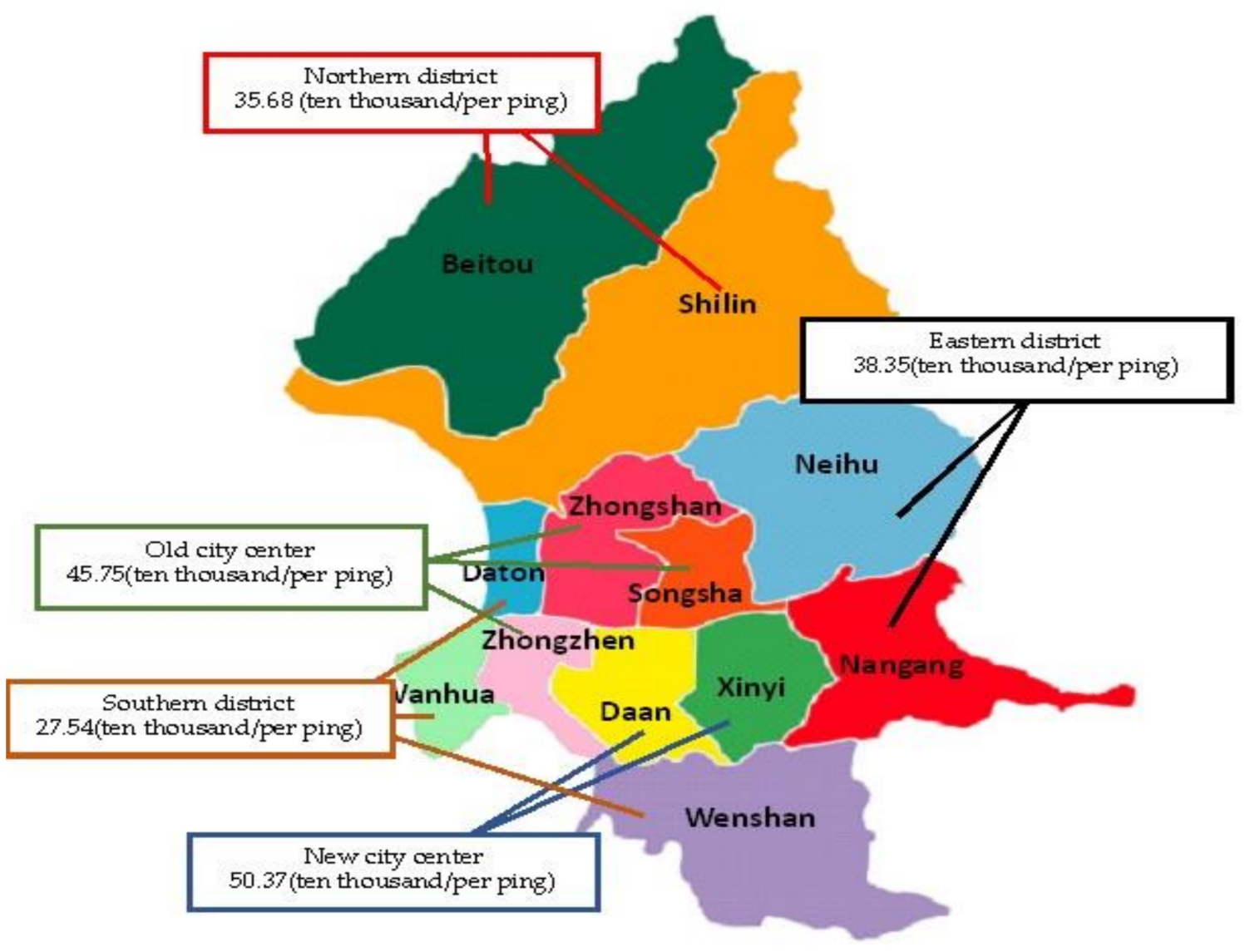

Figure 1. Average house transaction unit (ten thousand/per ping) price in each district of Taipei City. 
In order to clearly express the actual information gathered on real estate in Taipei City, Table 4 would classify the descriptive statistics of the total transaction price, the building area, the unit price, and the age of the building into six categories, as explained below. In terms of the total transaction price, the data was divided into 6 categories of 5 million, 5.1-10 million, 10.1-20 million, 20.1-30 million, 30.1-50 million, and over 50 million. As seen in Table 4, most of the transactions fell in the category of the total transaction price of 10.1-20 million, accounting for $38 \%$, followed by the category of $5.1-10$ million at $26 \%$. There were only a few reports of transactions in the category of over 50 million, accounting for only $4 \%$. In terms of the building area, the data was divided into 6 categories: below 10 unit area, 11-20 unit area, 21-30 unit area, 31-40 unit area, 41-50 unit area, and over 50 unit area. As seen in Table 4, most transactions showed the buyers' interest in the category of $21-30$ unit area, accounting for $25 \%$, followed by the category of $31-40$ unit area at $22 \%$. The buyers were least interested in the building area below 10 units, accounting for only $5 \%$. In terms of the unit price, the data was divided into 6 categories of below 100 thousand, 110-300 thousand, 310-500 thousand, 510-700 thousand, 710-900 thousand, and over 910 thousand. As seen in Table 4, most transactions fell under the unit price between 310 and 500 thousand, accounting for $39 \%$, followed by the category of 510-700 thousand at $29 \%$. Housing with a unit price below 100 thousand had the least transactions, as there were no cases reported $(0 \%)$. Lastly, in terms of the age of a building, the data was divided into 6 categories of below 5 years, 6-10 years, 11-20 years, 21-30 years, 31-40 years, and over 40 years. As seen in Table 4, most buyers were interested in buildings that were around 21 to 30 years, accounting for $25 \%$, followed by the category of building age below 5 years at $22 \%$. Buyers were the least interested in buildings above 40 years in age, accounting for only $4 \%$.

Before the empirical analysis, monthly averages would be taken from each transaction data according to the transaction time so that a total of 72 records were in time sequence. Then, the administrative region data would be analyzed by time series regression. Afterwards, in order to analyze the details of the impact of influential factors on the highest and the lowest housing price, partial individual housing data was analyzed by cross-sectional regression. 
Table 4. Descriptive statistics for transaction price, the building area, the unit price, and the building's age.

\begin{tabular}{|c|c|c|c|c|c|c|c|c|c|c|c|c|c|}
\hline Total Transaction Price & 5 Million Below & $\%$ & 5.01-10 Million & $\%$ & 10.01-20 Million & $\%$ & 20.01-30 Million & $\%$ & 30.01-50 Million & $\%$ & 50 Million over & $\%$ & All Sample \\
\hline Number/\% & 7043 & 8 & 22,251 & 26 & 32,210 & 38 & 12,486 & 15 & 7369 & 9 & 3810 & 4 & 85,169 \\
\hline Building area & 10 unit area below & $\%$ & $11-20$ unit area & $\%$ & $21-30$ unit area & $\%$ & $31-40$ unit area & $\%$ & $41-50$ unit area & $\%$ & 50 unit area over & $\%$ & total \\
\hline Number/\% & 3914 & 5 & 18,107 & 21 & 21,180 & 25 & 18,595 & 22 & 9205 & 11 & 14,168 & 17 & 85,169 \\
\hline Unit price & 100 thousand below & $\%$ & 110-300 thousand & $\%$ & $310-500$ thousand & $\%$ & $510-700$ thousand & $\%$ & $710-900$ thousand & $\%$ & 900 thousand over & $\%$ & total \\
\hline Number/\% & 1 & 0 & 12,274 & 14 & 33,224 & 39 & 24,360 & 29 & 10,178 & 12 & 5132 & 6 & 85,169 \\
\hline Building's age & 5 years below & $\%$ & $6-10$ years & $\%$ & $11-20$ years & $\%$ & $21-30$ years & $\%$ & $31-40$ years & $\%$ & 40 years over & $\%$ & total \\
\hline Number $/ \%$ & 18,995 & 22 & 8801 & 10 & 15,889 & 19 & 21,222 & 25 & 17,031 & 20 & 3231 & 4 & 85,169 \\
\hline
\end{tabular}

The period is from June 2008 to May 2014. 


\subsection{Empirical Model}

Based on review of these literatures, the semilogarithmic linear model and the natural logarithmic model were used for the unit area price. Many variables of a valuation model represented some of the characteristics or heterogeneity of the real estate. The conditional distribution was often heterogeneous and skewed. Natural logarithm could significantly reduce this problem and limit the influence of some extreme values.

Sirmans et al. [45] pointed out that taking the logarithm of housing prices in the Hedonic price model was a common assumption for normalizing data distribution and reducing error terms. The analysis by Del Giudice et al. [46] estimates a hedonic price function using a semiparametric regression based on Penalized Spline Smoothing, and compares the price prediction performance with conventional parametric models. The excellent results obtained show that the semiparametric models allow researchers to obtain significant improvement in the prediction of housing sale prices. The analysis by Del Giudice V. et al. [47] in the field of real estate appraisals states that oftentimes there is low transparency with regard to market information, together with stationary conditions, and these aspects force the analysts to work with single and small datasets for the implementation of hedonic pricing models. In Chen, M.-C.'s [48] analysis, the only form of housing market data available for long-term analysis in Taiwan are pre-sale house prices and the government survey of house price index. The government survey house price data, released since 1994 from the Directorate General of Budget, Accounting and Statistics, is based on detailed attributes of houses on an annual basis. In a comparative study of the government survey data and transaction data from estate agents to estimate annual quality-fixed house prices, Chang [49] found that the government survey data appears to offer a better quality. Therefore, monthly average price of unit area in Taipei City are used in the Hedonic price model during the research.

Model (4-1) uses overall average house prices in each district of Taipei City to explore the significance or relevance of the building characteristics, the macroeconomic characteristics, and housing polices.

This study would take the monthly average of individual house pricing data by the month of transaction. The model (4-1) was shown as follows:

$$
\log \left(S P_{t}\right)=\alpha+\Sigma_{j=1}^{M} r_{j} X_{t}^{j}+\Sigma_{j=1}^{K} \beta_{j} W_{t-1}^{j}+\theta_{1} D_{1 t}+\theta_{2} D_{2 t}+\varnothing_{t}
$$

in which, $S P_{t}$ was the monthly average transaction unit price of the $t$ record, $X_{t}^{j}$ represented the individual building characteristics, such as building area, floor number, age, and etc., $j$ was the number of variables in the category. $W_{t-1}^{j}$ represented the macroeconomic characteristics of previous period, including mortgage burden (\%), rental index, real estate (possible turnover) index (\%), economic growth rate (\%), mortgage rate (\%), inflation rate (\%), and M1B money supply growth rate (\%). D was the variable of housing policy, $D_{1 t}$ was the policy of luxury tax, and $D_{2 t}$ was the policy of the actual pricing registration.

Model (4-2) uses the house price of each transaction in each district of Taipei City to identify the significance or relevance of building characteristics, administrative regions, building types, and housing policies. For the individual housing characteristics, this study also used the Hedonic price model for buildings as seen in (4-2):

$$
\log \left(S P_{i}\right)=\alpha+\Sigma_{j=1}^{M} r_{j} X_{i}^{j}+\Sigma_{j=1}^{K} \theta_{1 j} D_{1 i}^{j}+\Sigma_{j=1}^{L} \theta_{2 j} D_{2 i}^{j}+\Sigma_{j=1}^{I} \theta_{3 j} D_{3 i}^{j}+\varnothing_{i}
$$

in which, $S P_{i}$ was the $i$ record of individual transaction unit price, $X_{i}^{j}$ represented individual building characteristics, such as building area, age, parking space (the variables of housing characteristics in the Equation (4-1) did not include parking space because Equation (4-1) used the monthly average data. The implication of variable of parking space would be affected if only its average was used and thus, it was not included), and etc., $j$ was the number of variables in the category. $D_{1 i}$ Represented every administrative region in Taipei City, including Chungcheng, Tatung, Chungshan, Songshan, Daan, 
Wanhua, Sinyi, Shihlin, Beitou, Neihu, Nangang, and Wenshan, where there were 11 virtual variables with the Neihu district set as the baseline region. $D_{2 i}$ represented the variables of the building type, including high-rise building, mansion, apartment, condo, townhouse, and villa, in a total of 5 virtual variables with the villa set as the basic building type. $D_{3 i}$ represented the variables of the housing policy, including the luxury tax and the actual pricing registration, in a total of 2 virtual variables.

\subsection{Variable Selection Instruction}

Table 5 showed the instruction of variables and the expected signs of corresponding influence on these variables in this study. The unit price of real estate transaction was the total price divided by the building area.

Table 5. Variable specification.

\begin{tabular}{|c|c|c|}
\hline Name of Variable & Unit & Variable Specification \\
\hline \multicolumn{3}{|c|}{ Dependent Variable } \\
\hline Transaction unit price & ten thousand & Take natural $\log$ of unit area price \\
\hline \multicolumn{3}{|c|}{ Independent Variable-Building Characteristics } \\
\hline Building area & Unit area & $\begin{array}{c}\text { Expected sign (direction) of influence could be negative or positive } \\
\text { and natural log of the value was taken. }\end{array}$ \\
\hline Floor & Floor & Expected sign (direction) of influence could be negative or positive. \\
\hline Building's age & Year & Expected sign (direction) of influence could be negative or positive. \\
\hline Administrative region & dummy variable & Expected sign (direction) of influence was negative or positive. \\
\hline Building type & dummy variable & Expected sign (direction) of influence was negative or positive. \\
\hline \multicolumn{3}{|c|}{ Independent Variable-Macroeconomic Characteristics } \\
\hline Mortgage burden & $(\%)$ & Expected sign (direction) of influence was positive. \\
\hline Rent index & $(\%)$ & Expected sign (direction) of influence was positive. \\
\hline real estate index (possible turnover) & $(\%)$ & Expected sign (direction) of influence was positive. \\
\hline Economic growth rate & $(\%)$ & Expected sign (direction) of influence was positive. \\
\hline mortgage rate & $(\%)$ & Expected sign (direction) of influence was negative. \\
\hline Inflation rate & $(\%)$ & Expected sign (direction) of influence was positive. \\
\hline M1B money supply growth rate & $(\%)$ & Expected sign (direction) of influence was positive. \\
\hline \multicolumn{3}{|c|}{ Independent Variable- Housing Policy } \\
\hline Luxury tax & dummy variable & Expected sign (direction) of influence was negative. \\
\hline Actual pricing registration & dummy variable & Expected sign (direction) of influence was negative. \\
\hline
\end{tabular}

From Figure 2, Average house transaction price per ping in Taipei city and each district, the monthly average of unit price for housing continued to rise from June 2008 to May 2014. As shown in Figure 2, for the monthly average of unit price in Taipei City, the lowest price of 325,100 was recorded in January 2009 and the highest price of 676,300 was seen in May 2014.

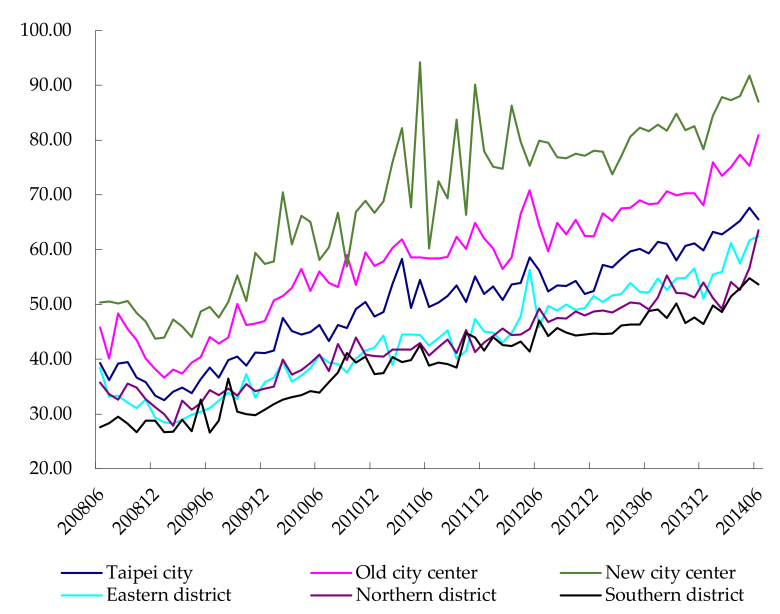

Figure 2. Average house transaction unit price (ten thousand per ping) in Taipei city and each district. 


\section{Empirical Analysis}

\subsection{Empirical Results of the Factors Influencing the Average Housing Prices in Taipei City and Each District}

Table 6 shows the empirical result of influential factors on the overall average price of a house in Taipei City. From the first column, ordinary least squares (OLS) estimates, mortgage rate had a significantly negative impact on housing prices, with an increase of $13.41 \%$ for every $1 \%$ drop in mortgage interest. In addition, the rent index, the real estate index (possible turnover), the economic growth rate, and the inflation rate all showed a positive influence on housing prices. On the other hand, M1B money supply growth rate and the actual pricing registration had a significantly negative impact on housing prices. With the exception of M1B money supply growth rate, other factors were consistent with the expected sign (direction of development).

Table 6 also lists the estimated result of quantile regression. Due to the differences in house pricing, the type and the degree of impact of influential factors might also differ. The authors of this paper believe that such discrepancies could be demonstrated by quantile regression. The result was identical to the expectation that mortgage rate showed a significantly negative influence on housing prices and these cases were mostly housing with medium prices at $\theta=0.25$ and $\theta=0.5$. In terms of coefficients, $\theta$ $=0.1$ and $\theta=0.9$ had the smallest coefficients, while the housing in between the quantiles showed increasing coefficients toward the center with $\theta=0.5$ showing the absolute coefficient value at -0.171 , which implied a drop of $17.11 \%$ in housing prices for every $1 \%$ in mortgage rate. For example, for every incremental increase of $0.25 \%$ in the mortgage rate, the overall average of housing prices in Taipei City could down-regulate by $4.28 \%$. In terms of the unit area price of 500,000 , another 21,400 could be subtracted. For example, the total price of a house with a 40 unit area could decrease by as much as 856,000 .

Table 6. Empirical results of the factors influencing the average housing prices in Taipei city.

\begin{tabular}{|c|c|c|c|c|c|c|}
\hline Taipei City & OLS & q10 & $\mathrm{q} 25$ & q50 & $\mathrm{q} 75$ & q90 \\
\hline c & $\begin{array}{l}-67.6246 \\
(15.7218)\end{array}$ & $\begin{array}{l}-60.6570 \\
(33.6329)\end{array}$ & $\begin{array}{c}-61.2988 \\
(26.1029)\end{array}$ & $\begin{array}{c}-60.3992 \\
(22.1248)\end{array}$ & $\begin{array}{l}-76.0239 \\
(33.4144)\end{array}$ & $\begin{array}{c}-102.2765 \\
(21.8454)\end{array}$ \\
\hline \multicolumn{7}{|l|}{ Building characteristics } \\
\hline Log (building area) & $\begin{array}{c}0.0505 \\
(0.1476)\end{array}$ & $\begin{array}{l}-0.1076 \\
(0.4563)\end{array}$ & $\begin{array}{l}-0.1819 \\
(0.2972)\end{array}$ & $\begin{array}{c}0.0967 \\
(0.2047)\end{array}$ & $\begin{array}{c}0.2243 \\
(0.2795)\end{array}$ & $\begin{array}{c}0.0868 \\
(0.2465)\end{array}$ \\
\hline Floor & $\begin{array}{c}0.0837 \\
(0.1411) \\
\end{array}$ & $\begin{array}{c}0.4168 \\
(0.1547) \\
\end{array}$ & $\begin{array}{c}0.1970 \\
(0.1601) \\
\end{array}$ & $\begin{array}{c}0.0838 \\
(0.2032) \\
\end{array}$ & $\begin{array}{l}-0.1166 \\
(0.4383) \\
\end{array}$ & $\begin{array}{l}-0.3863 \\
(0.3287) \\
\end{array}$ \\
\hline Age of building & $\begin{array}{l}-0.0125 \\
(0.0676)\end{array}$ & $\begin{array}{l}-0.0025 \\
(0.1466)\end{array}$ & $\begin{array}{l}-0.0486 \\
(0.0987)\end{array}$ & $\begin{array}{l}-0.0504 \\
(0.0895)\end{array}$ & $\begin{array}{c}0.0515 \\
(0.1563)\end{array}$ & $\begin{array}{l}-0.0665 \\
(0.0837)\end{array}$ \\
\hline \multicolumn{7}{|l|}{ Macroeconomic characteristics } \\
\hline Mortgage burden (\%) & $\begin{array}{c}0.2494 \\
(0.2003)\end{array}$ & $\begin{array}{c}0.5917 \\
(0.4742)\end{array}$ & $\begin{array}{c}0.2028 \\
(0.3426)\end{array}$ & $\begin{array}{c}0.1887 \\
(0.2519)\end{array}$ & $\begin{array}{c}0.4033 \\
(0.4343)\end{array}$ & $\begin{array}{c}\mathbf{0 . 6 7 5 0} \\
(0.2167)\end{array}$ \\
\hline Rental index (\%) & $\begin{array}{l}\mathbf{1 2 . 4 8 7 6} \\
(3.6664) \\
\end{array}$ & $\begin{array}{l}\mathbf{1 3 . 4 5 3 2} \\
(6.7464) \\
\end{array}$ & $\begin{array}{l}\mathbf{1 1 . 6 0 4 2} \\
(6.0149)\end{array}$ & $\begin{array}{c}\mathbf{9 . 6 4 8 0} \\
(5.3552)\end{array}$ & $\begin{array}{l}14.0191 \\
(9.1223)\end{array}$ & $\begin{array}{l}21.0084 \\
(5.4165)\end{array}$ \\
\hline Possible turnover index (\%) & $\begin{array}{c}\mathbf{0 . 5 4 9 5} \\
(0.1961)\end{array}$ & $\begin{array}{c}0.4367 \\
(0.3466)\end{array}$ & $\begin{array}{c}\mathbf{0 . 5 6 3 2} \\
(0.3329)\end{array}$ & $\begin{array}{c}\mathbf{0 . 6 5 1 0} \\
(0.2918)\end{array}$ & $\begin{array}{c}0.4237 \\
(0.4379)\end{array}$ & $\begin{array}{l}-0.0593 \\
(0.2458)\end{array}$ \\
\hline Economic growth rate (\%) & $\begin{array}{c}\mathbf{0 . 0 0 5 5} \\
(0.0016)\end{array}$ & $\begin{array}{c}0.0044 \\
(0.0041)\end{array}$ & $\begin{array}{c}\mathbf{0 . 0 0 4 6} \\
(0.0022)\end{array}$ & $\begin{array}{c}\mathbf{0 . 0 0 4 2} \\
(0.0021)\end{array}$ & $\begin{array}{c}0.0026 \\
(0.0047)\end{array}$ & $\begin{array}{c}0.0052 \\
(0.0048)\end{array}$ \\
\hline Mortgage rate (\%) & $\begin{array}{l}\mathbf{0 . 1 3 4 1} \\
(0.0489) \\
\end{array}$ & $\begin{array}{l}-0.0601 \\
(0.0881) \\
\end{array}$ & $\begin{array}{l}\mathbf{0 . 1 4 6 1} \\
(0.0755) \\
\end{array}$ & $\begin{array}{c}\mathbf{0 . 1 7 1 1} \\
(0.0722) \\
\end{array}$ & $\begin{array}{l}-0.1059 \\
(0.1162) \\
\end{array}$ & $\begin{array}{l}-0.0629 \\
(0.0687) \\
\end{array}$ \\
\hline Inflation rate (\%) & $\begin{array}{c}2.2665 \\
(1.1062) \\
\end{array}$ & $\begin{array}{l}-0.4399 \\
(2.3242) \\
\end{array}$ & $\begin{array}{c}1.9603 \\
(2.2002) \\
\end{array}$ & $\begin{array}{c}.4946 \\
(1.7609) \\
\end{array}$ & $\begin{array}{c}2.4506 \\
(2.7608) \\
\end{array}$ & $\begin{array}{c}1.6774 \\
(1.4478) \\
\end{array}$ \\
\hline M1b money supply growth rate (\%) & $\begin{array}{l}-0.0159 \\
(0.0059)\end{array}$ & $\begin{array}{l}-0.0120 \\
(0.0074)\end{array}$ & $\begin{array}{l}\mathbf{- 0 . 0 1 3 9} \\
(0.0072)\end{array}$ & $\begin{array}{l}-0.0215 \\
(0.0072)\end{array}$ & $\begin{array}{l}-0.0165 \\
(0.0151)\end{array}$ & $\begin{array}{l}-0.0126 \\
(0.0115)\end{array}$ \\
\hline \multicolumn{7}{|l|}{ Housing policy } \\
\hline Luxury tax & $\begin{array}{l}-0.0527 \\
(0.0349)\end{array}$ & $\begin{array}{l}-0.1074 \\
(0.1837)\end{array}$ & $\begin{array}{l}-0.0178 \\
(0.0564)\end{array}$ & $\begin{array}{l}-0.0560 \\
(0.0431)\end{array}$ & $\begin{array}{l}-0.0942 \\
(0.0530)\end{array}$ & $\begin{array}{l}-0.0794 \\
(0.0396)\end{array}$ \\
\hline Actual pricing registration & $\begin{array}{l}-\mathbf{0 . 1 4 5 1} \\
(0.0384)\end{array}$ & $\begin{array}{l}-0.0474 \\
(0.0487)\end{array}$ & $\begin{array}{l}-\mathbf{0 . 1 3 7 8} \\
(0.0776)\end{array}$ & $\begin{array}{l}-\mathbf{0 . 1 6 2 2} \\
(0.0515)\end{array}$ & $\begin{array}{l}\mathbf{- 0 . 1 5 8 6} \\
(0.0570)\end{array}$ & $\begin{array}{l}\mathbf{- 0 . 1 7 9 2} \\
(0.0547)\end{array}$ \\
\hline R-squared/Pseudo- $\mathrm{R}^{2}$ & 0.9525 & 0.8373 & 0.8319 & 0.8140 & 0.7679 & 0.7499 \\
\hline Adjusted- $R^{2}$ & 0.9429 & 0.8042 & 0.7977 & 0.7761 & 0.7206 & 0.6991 \\
\hline Durbin-Watson stat & 1.7685 & & & & & \\
\hline
\end{tabular}

Standard deviation in parentheses; red characters indicate significance on $p$-value $<0.1$. 
As for other independent variables such as the rent index, the real estate index (possible turnover), the economic growth rate, and the inflation rate, all showed a positive influence on houses with median prices. Specifically, the policy of implementing the actual pricing registration was indeed suppressive to housing in all quantiles. After the actual pricing registration was implemented, housing prices were reduced by $5 \%$ to $17 \%$.

In summary, the mortgage rate and the actual pricing registration were the most important factors affecting pricing. Therefore, if the objective was to suppress housing prices in Taipei City, the best action would be to start with the fundamentals and proceed with information transparency. The M1B money supply growth rate on the impact of housing prices was not as expected. It was probably due to decreases in other interest rates in the financial market despite the increased mortgage interest from the increasing money supply. Increases in other financial asset prices would naturally exclude the real estate market. Furthermore, Table 6 also demonstrates less impact on the overall average housing prices and the age of the building characteristics, except in one case, where the variable of floor showed a significantly positive effect.

The result of quantile regression of Table 7 shows that the mortgage rate showed a significantly negative influence on house prices and these cases were mostly housings with medium prices at $\theta=0.5$. When the mortgage rate was low, the public showed a greater willingness to purchase and the real estate market moved in a positive direction, which in turn led to increased pricing. Therefore, it was said to have a negative influence on housing prices. In terms of coefficient, $\theta=0.1$ and $\theta=0.75$ had the smallest coefficients, while the housings in between the quantiles showed increasing coefficients toward the center with $\theta=0.5$ showing the absolute coefficient value at -0.166 , which implied a suppressive effect by $16.62 \%$ on house prices for every $1 \%$ in mortgage interest rate. As for the other independent variables, the mortgage burden, the real estate index (possible turnover), the economic growth rate, and the inflation rate all had a significantly positive effect on housing prices, especially the economic growth rate, where a higher value suggested a better economy and a greater ability for the buyers in the region to purchase housing. Thus, it can be said to have a positive influence on housing prices. In terms of coefficients, the coefficient was at the maximum at $\theta=0.9$. It implied that for every $1 \%$ in the economic growth rate, the housing prices at the high end of the quantiles would increase by $2.15 \%$. Moreover, the inflation rate could affect the pricing of houses at the median level, $\theta=0.1, \theta=0.25$, and $\theta=0.5$. 
Table 7. Empirical results of the factors influencing the average housing prices in old city.

\begin{tabular}{|c|c|c|c|c|c|c|}
\hline Old City Center & OLS & q10 & $\mathrm{q} 25$ & q50 & q75 & $\mathrm{q} 90$ \\
\hline c & $\begin{array}{l}-27.3807 \\
(28.7469)\end{array}$ & $\begin{array}{l}-29.0721 \\
(21.5375)\end{array}$ & $\begin{array}{l}-45.0273 \\
(27.1534)\end{array}$ & $\begin{array}{l}-39.1476 \\
(22.4772)\end{array}$ & $\begin{array}{l}-49.2775 \\
(42.7467)\end{array}$ & $\begin{array}{l}-38.1514 \\
(58.6531)\end{array}$ \\
\hline \multicolumn{7}{|l|}{ Building characteristics } \\
\hline Log (building area) & $\begin{array}{c}-0.0474 \\
(0.0780)\end{array}$ & $\begin{array}{l}-\mathbf{0 . 1 4 6 3} \\
(0.0451)\end{array}$ & $\begin{array}{c}-\mathbf{0 . 2 4 8 3} \\
(0.0816)\end{array}$ & $\begin{array}{l}-0.0705 \\
(0.0621)\end{array}$ & $\begin{array}{l}-0.0624 \\
(0.0646)\end{array}$ & $\begin{array}{c}0.0569 \\
(0.1530)\end{array}$ \\
\hline Floor & $\begin{array}{c}0.1403 \\
(0.0922)\end{array}$ & $\begin{array}{c}\mathbf{0 . 2 8 4 6} \\
(0.0988)\end{array}$ & $\begin{array}{c}\mathbf{0 . 2 0 4 2} \\
(0.0886)\end{array}$ & $\begin{array}{c}0.0991 \\
(0.0925)\end{array}$ & $\begin{array}{c}0.1210 \\
(0.0893)\end{array}$ & $\begin{array}{c}0.1084 \\
(0.2403)\end{array}$ \\
\hline Age of building & $\begin{array}{l}-0.0197 \\
(0.0580)\end{array}$ & $\begin{array}{l}-0.0231 \\
(0.0512)\end{array}$ & $\begin{array}{l}-0.0439 \\
(0.0554)\end{array}$ & $\begin{array}{l}-0.0469 \\
(0.0509)\end{array}$ & $\begin{array}{l}-0.0177 \\
(0.0544)\end{array}$ & $\begin{array}{l}-0.0601 \\
(0.0972)\end{array}$ \\
\hline \multicolumn{7}{|l|}{ Macroeconomic characteristics } \\
\hline Mortgage burden (\%) & $\begin{array}{c}0.3191 \\
(0.3661)\end{array}$ & $\begin{array}{c}0.0050 \\
(0.2966)\end{array}$ & $\begin{array}{c}0.3920 \\
(0.4059)\end{array}$ & $\begin{array}{c}0.2580 \\
(0.3545)\end{array}$ & $\begin{array}{c}\mathbf{0 . 7 3 1 7} \\
(0.4040)\end{array}$ & $\begin{array}{l}-0.0702 \\
(0.4655)\end{array}$ \\
\hline Rental index (\%) & $\begin{array}{c}3.5822 \\
(6.8256)\end{array}$ & $\begin{array}{l}-3.2242 \\
(5.3050)\end{array}$ & $\begin{array}{l}5.8770 \\
(6.5580)\end{array}$ & $\begin{array}{c}5.6440 \\
(5.2664) \\
\end{array}$ & $\begin{array}{c}8.8884 \\
(10.4716)\end{array}$ & $\begin{array}{c}6.8157 \\
(12.4562)\end{array}$ \\
\hline Possible turnover index (\%) & $\begin{array}{c}0.3411 \\
(0.3183)\end{array}$ & $\begin{array}{c}\mathbf{0 . 7 2 2 2} \\
(0.2693)\end{array}$ & $\begin{array}{c}0.3419 \\
(0.3003)\end{array}$ & $\begin{array}{c}0.3416 \\
(0.2952)\end{array}$ & $\begin{array}{l}-0.0645 \\
(0.3637)\end{array}$ & $\begin{array}{c}0.4875 \\
(0.5908)\end{array}$ \\
\hline Economic growth rate (\%) & $\begin{array}{c}\mathbf{0 . 0 0 7 7} \\
(0.0029)\end{array}$ & $\begin{array}{c}\mathbf{0 . 0 0 4 6} \\
(0.0023)\end{array}$ & $\begin{array}{c}0.0022 \\
(0.0041)\end{array}$ & $\begin{array}{c}\mathbf{0 . 0 0 6 7} \\
(0.0033)\end{array}$ & $\begin{array}{c}0.0048 \\
(0.0054)\end{array}$ & $\begin{array}{c}\mathbf{0 . 0 2 1 5} \\
(0.0063)\end{array}$ \\
\hline Mortgage rate (\%) & $\begin{array}{l}-0.1247 \\
(0.0860)\end{array}$ & $\begin{array}{l}-\mathbf{0 . 1 0 3 0} \\
(0.0495)\end{array}$ & $\begin{array}{l}-0.1047 \\
(0.0808)\end{array}$ & $\begin{array}{l}-\mathbf{0 . 1 6 6 2} \\
(0.0779)\end{array}$ & $\begin{array}{l}-0.1034 \\
(0.0895)\end{array}$ & $\begin{array}{l}-0.1564 \\
(0.1151)\end{array}$ \\
\hline Inflation rate (\%) & $\begin{array}{c}2.6814 \\
(1.8433)\end{array}$ & $\begin{array}{c}4.0482 \\
(1.1943)\end{array}$ & $\begin{array}{c}4.2847 \\
(1.6110)\end{array}$ & $\begin{array}{c}3.2997 \\
(1.7506)\end{array}$ & $\begin{array}{c}2.2068 \\
(1.9769)\end{array}$ & $\begin{array}{c}1.9466 \\
(2.1448)\end{array}$ \\
\hline M1B money supply growth rate (\%) & $\begin{array}{l}-0.0155 \\
(0.0096)\end{array}$ & $\begin{array}{l}-\mathbf{0 . 0 1 2 2} \\
(0.0063)\end{array}$ & $\begin{array}{l}-0.0145 \\
(0.0108)\end{array}$ & $\begin{array}{l}-0.0237 \\
(0.0063)\end{array}$ & $\begin{array}{l}-0.0244 \\
(0.0134)\end{array}$ & $\begin{array}{c}0.0124 \\
(0.0263)\end{array}$ \\
\hline \multicolumn{7}{|l|}{ Housing policy } \\
\hline Luxury tax & $\begin{array}{l}-0.0111 \\
(0.0563)\end{array}$ & $\begin{array}{c}0.0192 \\
(0.0443)\end{array}$ & $\begin{array}{l}-0.0883 \\
(0.0998)\end{array}$ & $\begin{array}{l}-0.0094 \\
(0.0654)\end{array}$ & $\begin{array}{l}-0.0338 \\
(0.0703)\end{array}$ & $\begin{array}{c}0.0869 \\
(0.0843)\end{array}$ \\
\hline Actual pricing registration & $\begin{array}{l}-0.0372 \\
(0.0688)\end{array}$ & $\begin{array}{c}0.0398 \\
(0.0454)\end{array}$ & $\begin{array}{l}-0.0324 \\
(0.0888)\end{array}$ & $\begin{array}{l}-\mathbf{0 . 1 0 5 1} \\
(0.0755)\end{array}$ & $\begin{array}{l}-0.0818 \\
(0.1125)\end{array}$ & $\begin{array}{l}-0.1063 \\
(0.1483)\end{array}$ \\
\hline R-squared/Pseudo- $R^{2}$ & 0.8676 & 0.7579 & 0.7274 & 0.6827 & 0.6130 & 0.5617 \\
\hline Adjusted- $R^{2}$ & 0.8406 & 0.7087 & 0.6719 & 0.6181 & 0.5343 & 0.4725 \\
\hline Durbin-Watson stat & 2.4795 & & & & & \\
\hline
\end{tabular}

In addition, Table 7 also showed the variables of building characteristics with impact on the overall average house pricing, where the building area had a negative effect and the floor had a positive effect.

Table 8 shows the empirical result of the influential factors on the overall average housing prices in the new city center. Based on the ordinary least squares (OLS) estimates, the real estate index (possible turnover), the economic growth rate, and the inflation rate had a significantly positive effect on housing prices, while the mortgage rate and the M1B money supply growth rate had a significantly negative effect on housing prices. For every $1 \%$ increase in the mortgage rate, the price of a house, on average, would decrease by $16.44 \%$. With the exception of the M1B money supply, the other factors were consistent with the expected sign (direction of development). 
Table 8. Empirical results of the factors influencing average housing prices in new city center.

\begin{tabular}{|c|c|c|c|c|c|c|}
\hline New City Center & OLS & q10 & $\mathrm{q} 25$ & q50 & q75 & q90 \\
\hline c & $\begin{array}{l}-41.5116 \\
(24.4038)\end{array}$ & $\begin{array}{l}-78.7294 \\
(35.7161)\end{array}$ & $\begin{array}{l}-49.2174 \\
(19.8424)\end{array}$ & $\begin{array}{l}-41.2281 \\
(22.2265)\end{array}$ & $\begin{array}{l}-63.6982 \\
(26.3289)\end{array}$ & $\begin{array}{l}-78.1168 \\
(35.2518)\end{array}$ \\
\hline \multicolumn{7}{|l|}{ Building characteristics } \\
\hline Log (building area) & $\begin{array}{l}-\mathbf{0 . 0 8 0 0} \\
(0.0470)\end{array}$ & $\begin{array}{l}-0.0912 \\
(0.1006)\end{array}$ & $\begin{array}{l}-0.1206 \\
(0.1055)\end{array}$ & $\begin{array}{l}-0.0791 \\
(0.0651)\end{array}$ & $\begin{array}{l}-0.0777 \\
(0.1042)\end{array}$ & $\begin{array}{l}-0.0852 \\
(0.0670)\end{array}$ \\
\hline Floor & $\begin{array}{c}0.0513 \\
(0.0535)\end{array}$ & $\begin{array}{c}0.0797 \\
(0.2140)\end{array}$ & $\begin{array}{c}-0.0449 \\
(0.0467)\end{array}$ & $\begin{array}{c}0.0212 \\
(0.0588)\end{array}$ & $\begin{array}{c}0.1305 \\
(0.0864)\end{array}$ & $\begin{array}{c}0.0866 \\
(0.1176)\end{array}$ \\
\hline Age of building & $\begin{array}{l}-0.0143 \\
(0.0160)\end{array}$ & $\begin{array}{l}-0.0314 \\
(0.1410)\end{array}$ & $\begin{array}{l}-0.0526 \\
(0.0951)\end{array}$ & $\begin{array}{l}-0.0030 \\
(0.0299)\end{array}$ & $\begin{array}{l}-0.0014 \\
(0.1265)\end{array}$ & $\begin{array}{l}-0.0083 \\
(0.0114)\end{array}$ \\
\hline \multicolumn{7}{|l|}{ Macroeconomic characteristics } \\
\hline Mortgage burden (\%) & $\begin{array}{c}0.1822 \\
(0.3113) \\
\end{array}$ & $\begin{array}{c}0.3345 \\
(0.4279) \\
\end{array}$ & $\begin{array}{c}0.0207 \\
(0.4180) \\
\end{array}$ & $\begin{array}{c}0.1402 \\
(0.2742) \\
\end{array}$ & $\begin{array}{c}0.6306 \\
(0.3817) \\
\end{array}$ & $\begin{array}{c}0.9846 \\
(0.5996) \\
\end{array}$ \\
\hline Rental index (\%) & $\begin{array}{c}5.2257 \\
(5.8781) \\
\end{array}$ & $\begin{array}{l}\mathbf{1 4 . 1 4 9 0} \\
(8.1916) \\
\end{array}$ & $\begin{array}{c}7.5156 \\
(5.2219) \\
\end{array}$ & $\begin{array}{c}5.5117 \\
(5.4119) \\
\end{array}$ & $\begin{array}{l}\mathbf{1 2 . 2 1 0 0} \\
(6.7017)\end{array}$ & $\begin{array}{l}\mathbf{1 5 . 0 0 5 2} \\
(8.7472)\end{array}$ \\
\hline Possible turnover index (\%) & $\begin{array}{c}\mathbf{0 . 8 0 7 0} \\
(0.2860)\end{array}$ & $\begin{array}{c}0.3673 \\
(0.4008)\end{array}$ & $\begin{array}{c}\mathbf{0 . 6 8 1 7} \\
(0.3368)\end{array}$ & $\begin{array}{c}\mathbf{0 . 6 4 2 7} \\
(0.2753)\end{array}$ & $\begin{array}{c}0.3509 \\
(0.3858)\end{array}$ & $\begin{array}{c}0.4214 \\
(0.4337)\end{array}$ \\
\hline Economic growth rate (\%) & $\begin{array}{c}\mathbf{0 . 0 0 5 8} \\
(0.0024) \\
\end{array}$ & $\begin{array}{c}0.0033 \\
(0.0044) \\
\end{array}$ & $\begin{array}{c}\mathbf{0 . 0 0 7 3} \\
(0.0025) \\
\end{array}$ & $\begin{array}{c}\mathbf{0 . 0 0 7 0} \\
(0.0021) \\
\end{array}$ & $\begin{array}{c}\mathbf{0 . 0 0 9 1} \\
(0.0029)\end{array}$ & $\begin{array}{c}\mathbf{0 . 0 0 9 3} \\
(0.0032)\end{array}$ \\
\hline Mortgage rate (\%) & $\begin{array}{l}-\mathbf{0 . 1 6 4 4} \\
(0.0722)\end{array}$ & $\begin{array}{c}-\mathbf{0 . 1 5 9 8} \\
(0.0805)\end{array}$ & $\begin{array}{c}-\mathbf{0 . 1 7 4 9} \\
(0.0953)\end{array}$ & $\begin{array}{l}-\mathbf{0 . 1 6 2 0} \\
(0.0576)\end{array}$ & $\begin{array}{l}-0.0635 \\
(0.0716)\end{array}$ & $\begin{array}{l}-0.0228 \\
(0.1015)\end{array}$ \\
\hline Inflation rate (\%) & $\begin{array}{c}3.8521 \\
(1.6490)\end{array}$ & $\begin{array}{c}3.3200 \\
(2.1937)\end{array}$ & $\begin{array}{c}3.5777 \\
(2.3359)\end{array}$ & $\begin{array}{c}3.7003 \\
(1.2928)\end{array}$ & $\begin{array}{c}1.6817 \\
(1.5951)\end{array}$ & $\begin{array}{c}1.6734 \\
(1.6802)\end{array}$ \\
\hline M1B money supply growth rate (\%) & $\begin{array}{l}-\mathbf{0 . 0 1 6 5} \\
(0.0087)\end{array}$ & $\begin{array}{l}-\mathbf{0 . 0 2 7 7} \\
(0.0100)\end{array}$ & $\begin{array}{c}-\mathbf{0 . 0 1 4 5} \\
(0.0073)\end{array}$ & $\begin{array}{l}-\mathbf{0 . 0 1 5 7} \\
(0.0070)\end{array}$ & $\begin{array}{l}-0.0009 \\
(0.0089)\end{array}$ & $\begin{array}{l}-0.0024 \\
(0.0134)\end{array}$ \\
\hline \multicolumn{7}{|l|}{ Housing policy } \\
\hline Luxury tax & $\begin{array}{l}-0.0510 \\
(0.0510)\end{array}$ & $\begin{array}{l}-0.0832 \\
(0.0919)\end{array}$ & $\begin{array}{l}-0.0173 \\
(0.0749)\end{array}$ & $\begin{array}{l}-0.0063 \\
(0.0604)\end{array}$ & $\begin{array}{l}-0.0041 \\
(0.0951)\end{array}$ & $\begin{array}{l}-0.1471 \\
(0.0964)\end{array}$ \\
\hline Actual pricing registration & $\begin{array}{l}-\mathbf{0 . 1 5 1 4} \\
(0.0545)\end{array}$ & $\begin{array}{l}-0.1599 \\
(0.1152)\end{array}$ & $\begin{array}{l}-0.0957 \\
(0.0533)\end{array}$ & $\begin{array}{l}-\mathbf{0 . 1 1 8 1} \\
(0.0503)\end{array}$ & $\begin{array}{l}-\mathbf{0 . 2 2 5 4} \\
(0.0615)\end{array}$ & $\begin{array}{c}-\mathbf{0 . 2 8 6 2} \\
(0.0973)\end{array}$ \\
\hline R-squared/Pseudo- $R^{2}$ & 0.9075 & 0.7817 & 0.7920 & 0.7637 & 0.6802 & 0.6233 \\
\hline Adjusted-R ${ }^{2}$ & 0.8887 & 0.7373 & 0.7496 & 0.7156 & 0.6152 & 0.5466 \\
\hline Durbin-Watson stat & 2.4681 & & & & & \\
\hline
\end{tabular}

Table 8 also lists the estimated result of quantile regression. The result was identical to the expectation that the mortgage rate showed a significantly negative influence on housing prices and these cases were mostly houses with low and medium prices at $\theta=0.1, \theta=0.25$, and $\theta=0.5$. In terms of coefficients, every $1 \%$ increase in interest rates could place a suppressive effect of approximately $16 \%$ to $17 \%$ on housing prices. Since the average transaction unit price in this district was generally over millions, when the mortgage rate was raised by one increment, the original unit area price of 1 million was estimated to fall by about 40,000. For example, the total price of a house with a 50 -unit area could decrease by as much as 2 million.

As for other independent variables such as the rent index, a higher value indicated higher rental costs. When an individual's income has not increased over the course of years, the individual who is reluctant to pay high rent would be motivated to purchase a house and use the rent money for the mortgage payment, resulting in a positive influence on housing prices.

Specifically, factors such as mortgage burden, economic growth rate, mortgage rate, inflation rate, and M1B money supply growth rate, as well as the luxury tax and the actual pricing registration, had significant impacts on housing prices.

The ordinary least squares (OLS) estimates in Table 9 showed that for every $1 \%$ increase in the economic growth rate, the average price of a house would increase $0.56 \%$. With the exception of M1B money supply, the other factors were consistent with the expected sign (direction of development). 
Table 9. Empirical results of the factors influencing the average housing prices in eastern district.

\begin{tabular}{|c|c|c|c|c|c|c|}
\hline Eastern District & OLS & q10 & q25 & q50 & q75 & q90 \\
\hline c & $\begin{array}{l}-81.4224 \\
(19.4584)\end{array}$ & $\begin{array}{l}-52.8812 \\
(23.9409)\end{array}$ & $\begin{array}{l}-36.4723 \\
(23.5464)\end{array}$ & $\begin{array}{l}-56.4251 \\
(24.2412)\end{array}$ & $\begin{array}{l}-94.2405 \\
(24.4971)\end{array}$ & $\begin{array}{c}-\mathbf{1 2 1 . 4 8 8 5} \\
(33.3719)\end{array}$ \\
\hline \multicolumn{7}{|l|}{ Building characteristics } \\
\hline Log (building area) & $\begin{array}{c}0.0004 \\
(0.0663)\end{array}$ & $\begin{array}{c}-0.0328 \\
(0.0733)\end{array}$ & $\begin{array}{l}-0.0270 \\
(0.0878)\end{array}$ & $\begin{array}{c}0.0201 \\
(0.0595)\end{array}$ & $\begin{array}{l}-0.0267 \\
(0.0768)\end{array}$ & $\begin{array}{l}-0.0131 \\
(0.1577)\end{array}$ \\
\hline Floor & $\begin{array}{l}-0.0511 \\
(0.1004)\end{array}$ & $\begin{array}{l}-0.1403 \\
(0.1498)\end{array}$ & $\begin{array}{l}-0.2556 \\
(0.1464)\end{array}$ & $\begin{array}{l}-0.1685 \\
(0.1010)\end{array}$ & $\begin{array}{l}-0.0791 \\
(0.1198)\end{array}$ & $\begin{array}{l}-0.0418 \\
(0.1873)\end{array}$ \\
\hline Age of building & $\begin{array}{l}-0.0348 \\
(0.0747) \\
\end{array}$ & $\begin{array}{l}-0.1530 \\
(0.1426)\end{array}$ & $\begin{array}{c}0.0156 \\
(0.1061)\end{array}$ & $\begin{array}{c}0.0320 \\
(0.0635)\end{array}$ & $\begin{array}{c}0.0514 \\
(0.0997)\end{array}$ & $\begin{array}{c}0.0060 \\
(0.1657)\end{array}$ \\
\hline \multicolumn{7}{|l|}{ Macroeconomic characteristics } \\
\hline Mortgage burden (\%) & $\begin{array}{c}\mathbf{0 . 4 9 6 0} \\
(0.2419)\end{array}$ & $\begin{array}{c}0.0717 \\
(0.3625)\end{array}$ & $\begin{array}{c}0.1032 \\
(0.3245)\end{array}$ & $\begin{array}{c}0.3365 \\
(0.2824)\end{array}$ & $\begin{array}{c}0.5315 \\
(0.2935)\end{array}$ & $\begin{array}{c}0.8663 \\
(0.5612)\end{array}$ \\
\hline Rental index (\%) & $\begin{array}{l}\mathbf{1 6 . 6 2 9 7} \\
(4.7903)\end{array}$ & $\begin{array}{c}8.6433 \\
(5.3704)\end{array}$ & $\begin{array}{c}4.0551 \\
(5.9679)\end{array}$ & $\begin{array}{l}\mathbf{1 0 . 2 6 6 7} \\
(5.6192)\end{array}$ & $\begin{array}{l}18.4774 \\
(6.1783)\end{array}$ & $\begin{array}{l}25.7721 \\
(8.5611)\end{array}$ \\
\hline Possible turnover index (\%) & $\begin{array}{c}0.1419 \\
(0.2203)\end{array}$ & $\begin{array}{c}\mathbf{0 . 4 5 5 1} \\
(0.2425)\end{array}$ & $\begin{array}{c}\mathbf{0 . 4 8 7 6} \\
(0.2795)\end{array}$ & $\begin{array}{c}0.2910 \\
(0.2400)\end{array}$ & $\begin{array}{c}0.1883 \\
(0.2580)\end{array}$ & $\begin{array}{l}-0.1516 \\
(0.5482)\end{array}$ \\
\hline Economic growth rate (\%) & $\begin{array}{c}\mathbf{0 . 0 0 5 6} \\
(0.0019)\end{array}$ & $\begin{array}{c}0.0053 \\
(0.0033)\end{array}$ & $\begin{array}{c}0.0022 \\
(0.0033)\end{array}$ & $\begin{array}{c}\mathbf{0 . 0 0 4 8} \\
(0.0018)\end{array}$ & $\begin{array}{c}\mathbf{0 . 0 0 4 1} \\
(0.0019)\end{array}$ & $\begin{array}{c}0.0042 \\
(0.0035)\end{array}$ \\
\hline Mortgage rate (\%) & $\begin{array}{l}-0.0486 \\
(0.0593)\end{array}$ & $\begin{array}{l}-\mathbf{0 . 1 7 5 3} \\
(0.1020)\end{array}$ & $\begin{array}{l}-\mathbf{0 . 1 5 7 2} \\
(0.0823)\end{array}$ & $\begin{array}{l}-0.0679 \\
(0.0598)\end{array}$ & $\begin{array}{l}-0.0450 \\
(0.0923)\end{array}$ & $\begin{array}{l}-0.1471 \\
(0.1448)\end{array}$ \\
\hline Inflation rate (\%) & $\begin{array}{c}1.3477 \\
(1.3414)\end{array}$ & $\begin{array}{c}3.3565 \\
(2.4691)\end{array}$ & $\begin{array}{c}4.2546 \\
(2.0861) \\
\end{array}$ & $\begin{array}{c}2.2598 \\
(1.1826) \\
\end{array}$ & $\begin{array}{c}2.1937 \\
(1.4554)\end{array}$ & $\begin{array}{c}0.8050 \\
(3.0192) \\
\end{array}$ \\
\hline M1B money supply growth rate (\%) & $\begin{array}{l}-0.0106 \\
(0.0070)\end{array}$ & $\begin{array}{l}-\mathbf{0 . 0 1 8 9} \\
(0.0105)\end{array}$ & $\begin{array}{c}-\mathbf{0 . 0 1 6 8} \\
(0.0081)\end{array}$ & $\begin{array}{l}-0.0066 \\
(0.0066)\end{array}$ & $\begin{array}{l}-0.0100 \\
(0.0071)\end{array}$ & $\begin{array}{l}-0.0080 \\
(0.0132)\end{array}$ \\
\hline \multicolumn{7}{|l|}{ Housing policy } \\
\hline Luxury tax & $\begin{array}{l}-0.0197 \\
(0.0407)\end{array}$ & $\begin{array}{c}0.0130 \\
(0.0953)\end{array}$ & $\begin{array}{l}-0.0083 \\
(0.0907)\end{array}$ & $\begin{array}{c}0.0092 \\
(0.0488)\end{array}$ & $\begin{array}{l}-0.0733 \\
(0.0446)\end{array}$ & $\begin{array}{l}-0.0456 \\
(0.0707)\end{array}$ \\
\hline Actual pricing registration & $\begin{array}{l}-0.0878 \\
(0.0451)\end{array}$ & $\begin{array}{l}-0.0220 \\
(0.0905)\end{array}$ & $\begin{array}{c}0.0004 \\
(0.0581)\end{array}$ & $\begin{array}{l}-0.0397 \\
(0.0500)\end{array}$ & $\begin{array}{l}-\mathbf{0 . 1 3 0 6} \\
(0.0554)\end{array}$ & $\begin{array}{l}-\mathbf{0 . 2 4 3 6} \\
(0.0796)\end{array}$ \\
\hline R-squared/Pseudo- $R^{2}$ & 0.9374 & 0.8139 & 0.8081 & 0.7836 & 0.7674 & 0.7312 \\
\hline Adjusted-R ${ }^{2}$ & 0.9246 & 0.7761 & 0.7690 & 0.7396 & 0.7201 & 0.6765 \\
\hline Durbin-Watson stat & 1.8441 & & & & & \\
\hline
\end{tabular}

The results of quantile regression in Table 9 show that mortgage rate showed a significantly negative influence on house prices and these cases were mostly houses with low and medium prices at $\theta=0.1$ and $\theta=0.25$. At a quantile of $\theta=0.1$, for every $1 \%$ increase in the mortgage rate, the house price would decrease by $17.53 \%$. Moreover, the real estate index, the mortgage rate, the inflation rate, the M1B money supply, and the actual pricing registration could significantly affect housing of medium prices at a quantile of $\theta=0.25$. This district consisted mostly of science parks and there were many landlords renting houses. In addition, the policy of actual pricing registration was suppressive to housing at high prices at quantiles of $\theta=0.75$ and $\theta=0.9$ in this district. In summary, with suppression of housing prices in the eastern district as the objective, it was necessary to proceed in dealing with the rent, the number of pre-sale house construction, the economy, the commodity pricing, and the information transparency.

The ordinary least squares (OLS) estimates in Table 10 showed that for every $1 \%$ increase in the economic growth rate, the average house price would increase by $0.39 \%$. As for the result of quantile regression, the mortgage rate showed a significantly negative influence on house prices. For every $1 \%$ increase in the mortgage rate, the house price was estimated to decrease by $7.30 \%$. As for other independent variables such as the mortgage burden, the rent index, the real estate index (possible turnover), the economic growth rate, and the inflation rate, all showed a positive influence. This district is more culturally and educationally oriented in term of its city planning. There were increases in housing and rental demand for office workers and students, as house prices were primarily 
affected by the mortgage burden, even though the rent index, the actual pricing registration, and the economic growth rate had suppressive effects on housing of medium price.

Table 10. Empirical results of the factors influencing average housing prices in northern district.

\begin{tabular}{|c|c|c|c|c|c|c|}
\hline Northern District & OLS & $\mathrm{q10}$ & $\mathrm{q} 25$ & q50 & q75 & q90 \\
\hline c & $\begin{array}{l}-51.6161 \\
(12.7373)\end{array}$ & $\begin{array}{l}-44.2512 \\
(16.5146)\end{array}$ & $\begin{array}{l}-35.4623 \\
(17.3163)\end{array}$ & $\begin{array}{l}-45.2037 \\
(21.3845)\end{array}$ & $\begin{array}{l}-66.0742 \\
(12.0856)\end{array}$ & $\begin{array}{l}\mathbf{- 5 3 . 0 6 9 1} \\
(23.8194)\end{array}$ \\
\hline \multicolumn{7}{|l|}{ Building characteristics } \\
\hline Log (building area) & $\begin{array}{c}0.0302 \\
(0.0302)\end{array}$ & $\begin{array}{c}0.0251 \\
(0.0468)\end{array}$ & $\begin{array}{c}0.0203 \\
(0.0363)\end{array}$ & $\begin{array}{c}0.0372 \\
(0.0481)\end{array}$ & $\begin{array}{c}0.0122 \\
(0.0240)\end{array}$ & $\begin{array}{c}0.0124 \\
(0.1210)\end{array}$ \\
\hline Floor & $\begin{array}{c}0.0324 \\
(0.0436)\end{array}$ & $\begin{array}{c}0.0658 \\
(0.0608)\end{array}$ & $\begin{array}{c}0.0068 \\
(0.0530)\end{array}$ & $\begin{array}{c}0.0018 \\
(0.0578)\end{array}$ & $\begin{array}{l}-0.0385 \\
(0.0456)\end{array}$ & $\begin{array}{c}0.0916 \\
(0.0741)\end{array}$ \\
\hline Age of building & $\begin{array}{c}\mathbf{0 . 0 7 9 1} \\
(0.0400)\end{array}$ & $\begin{array}{c}0.0671 \\
(0.0598)\end{array}$ & $\begin{array}{c}0.0217 \\
(0.0391)\end{array}$ & $\begin{array}{c}0.0625 \\
(0.0572)\end{array}$ & $\begin{array}{c}0.0965 \\
(0.0535)\end{array}$ & $\begin{array}{c}\mathbf{0 . 1 6 0 0} \\
(0.0839)\end{array}$ \\
\hline \multicolumn{7}{|l|}{ Macroeconomic characteristics } \\
\hline Mortgage burden (\%) & $\begin{array}{c}\mathbf{0 . 4 9 4 2} \\
(0.1617)\end{array}$ & $\begin{array}{c}\mathbf{0 . 5 9 4 5} \\
(0.2838)\end{array}$ & $\begin{array}{c}0.3234 \\
(0.2032)\end{array}$ & $\begin{array}{c}\mathbf{0 . 4 4 8 0} \\
(0.1937)\end{array}$ & $\begin{array}{c}\mathbf{0 . 5 7 1 8} \\
(0.1172)\end{array}$ & $\begin{array}{c}0.3728 \\
(0.3051)\end{array}$ \\
\hline Rental index (\%) & $\begin{array}{l}\mathbf{1 0 . 2 7 8 8} \\
(3.0599)\end{array}$ & $\begin{array}{c}8.2102 \\
(4.6812)\end{array}$ & $\begin{array}{c}5.7432 \\
(4.2686)\end{array}$ & $\begin{array}{c}8.5180 \\
(4.9850)\end{array}$ & $\begin{array}{l}14.1076 \\
(2.8610)\end{array}$ & $\begin{array}{l}\mathbf{1 1 . 1 4 0 8} \\
(5.8141)\end{array}$ \\
\hline Possible turnover index (\%) & $\begin{array}{c}0.1362 \\
(0.1454) \\
\end{array}$ & $\begin{array}{c}0.2162 \\
(0.1914)\end{array}$ & $\begin{array}{c}\mathbf{0 . 4 2 7 9} \\
(0.1643) \\
\end{array}$ & $\begin{array}{c}0.1385 \\
(0.1831)\end{array}$ & $\begin{array}{c}0.0073 \\
(0.1595)\end{array}$ & $\begin{array}{c}0.1871 \\
(0.2970)\end{array}$ \\
\hline Economic growth rate (\%) & $\begin{array}{c}\mathbf{0 . 0 0 3 9} \\
(0.0013)\end{array}$ & $\begin{array}{c}\mathbf{0 . 0 0 5 3} \\
(0.0025)\end{array}$ & $\begin{array}{c}0.0018 \\
(0.0023)\end{array}$ & $\begin{array}{c}\mathbf{0 . 0 0 3 4} \\
(0.0018)\end{array}$ & $\begin{array}{c}\mathbf{0 . 0 0 4 2} \\
(0.0012)\end{array}$ & $\begin{array}{c}\mathbf{0 . 0 0 5 3} \\
(0.0018)\end{array}$ \\
\hline Mortgage rate (\%) & $\begin{array}{l}-0.0176 \\
(0.0391)\end{array}$ & $\begin{array}{l}-0.0172 \\
(0.0952)\end{array}$ & $\begin{array}{l}-0.0730 \\
(0.0643)\end{array}$ & $\begin{array}{l}-0.0053 \\
(0.0520)\end{array}$ & $\begin{array}{l}-0.0290 \\
(0.0281)\end{array}$ & $\begin{array}{l}-0.0210 \\
(0.0672)\end{array}$ \\
\hline Inflation rate $(\%)$ & $\begin{array}{c}1.0899 \\
(0.8849)\end{array}$ & $\begin{array}{l}1.3685 \\
(2.0777)\end{array}$ & $\begin{array}{c}2.0472 \\
(1.2167)\end{array}$ & $\begin{array}{c}1.5073 \\
(1.1366)\end{array}$ & $\begin{array}{c}0.4777 \\
(0.5938)\end{array}$ & $\begin{array}{c}0.5379 \\
(1.7874)\end{array}$ \\
\hline M1B money supply growth rate (\%) & $\begin{array}{l}-\mathbf{0 . 0 1 0 4} \\
(0.0047)\end{array}$ & $\begin{array}{c}-0.0151 \\
(0.0088)\end{array}$ & $\begin{array}{l}-0.0099 \\
(0.0076)\end{array}$ & $\begin{array}{l}-0.0105 \\
(0.0069)\end{array}$ & $\begin{array}{l}-0.0029 \\
(0.0046)\end{array}$ & $\begin{array}{l}-0.0008 \\
(0.0071)\end{array}$ \\
\hline \multicolumn{7}{|l|}{ Housing policy } \\
\hline Luxury tax & $\begin{array}{l}-0.0384 \\
(0.0272)\end{array}$ & $\begin{array}{l}-0.0451 \\
(0.0342)\end{array}$ & $\begin{array}{l}-0.0455 \\
(0.0324)\end{array}$ & $\begin{array}{l}-0.0266 \\
(0.0306)\end{array}$ & $\begin{array}{l}-0.0451 \\
(0.0328)\end{array}$ & $\begin{array}{c}-0.0033 \\
(0.0603)\end{array}$ \\
\hline Actual pricing registration & $\begin{array}{l}-0.0148 \\
(0.0300)\end{array}$ & $\begin{array}{l}-0.0285 \\
(0.0446)\end{array}$ & $\begin{array}{l}-0.0209 \\
(0.0318)\end{array}$ & $\begin{array}{l}-0.0096 \\
(0.0386)\end{array}$ & $\begin{array}{l}-0.0400 \\
(0.0197)\end{array}$ & $\begin{array}{l}-0.0193 \\
(0.0569)\end{array}$ \\
\hline R-squared/Pseudo- $\mathrm{R}^{2}$ & 0.9582 & 0.8190 & 0.8228 & 0.8162 & 0.8140 & 0.8064 \\
\hline Adjusted- $R^{2}$ & 0.9497 & 0.7822 & 0.7868 & 0.7788 & 0.7761 & 0.7670 \\
\hline Durbin-Watson stat & 1.9533 & & & & & \\
\hline
\end{tabular}

Standard deviation in parentheses. Red characters indicate significance on $p$-value $<0.1$. Northern district includes Shihlin and Beitou administrative districts.

The quantile regression estimates in Table 11 showed a significantly negative influence on house prices and these cases were mostly housing with low and medium prices at $\theta=0.1$ and $\theta=0.25$. In term of coefficients, every $1 \%$ increase of mortgage interest could lead to a decrease of $11.51 \%$ to $17.49 \%$ on the average house price. As for the other independent variables such as the mortgage burden, the rent index, the real estate index (possible turnover), and the inflation rate, all showed a positive influence. Specifically, the real estate index, the mortgage rate, and the inflation rate could suppress housing of medium prices. Based on the above result, due to low average unit price and older buildings, plus fewer new housing available in the district, buyers would have to buy second-hand houses and consider the mortgage rate, as well as commodity pricing, which would affect their ability in affording the level of monthly mortgage. In terms of influential factors on house prices, the real estate index (possible turnover), the mortgage rate, the inflation rate, and the actual pricing registration were the major determinants. If suppression of house prices in the southern district was the objective, it was still necessary to proceed in adjusting the mortgage rate, the inflation rate, and the information transparency. 
Table 11. Empirical results of the influence factors to average house prices in southern district.

\begin{tabular}{|c|c|c|c|c|c|c|}
\hline Southern District & OLS & q10 & q25 & q50 & q75 & q90 \\
\hline c & $\begin{array}{l}-\mathbf{6 2 . 5 6 6 7} \\
(17.2772)\end{array}$ & $\begin{array}{l}-57.0191 \\
(31.2066)\end{array}$ & $\begin{array}{l}-27.6274 \\
(31.3231)\end{array}$ & $\begin{array}{l}-52.0879 \\
(26.1862)\end{array}$ & $\begin{array}{l}-57.4551 \\
(24.3636)\end{array}$ & $\begin{array}{c}-106.7201 \\
(40.9233)\end{array}$ \\
\hline \multicolumn{7}{|l|}{ Building characteristics } \\
\hline Log (building area) & $\begin{array}{l}-0.0807 \\
(0.0732)\end{array}$ & $\begin{array}{c}0.0681 \\
(0.1246)\end{array}$ & $\begin{array}{l}-0.0985 \\
(0.0964)\end{array}$ & $\begin{array}{l}-0.0254 \\
(0.0803)\end{array}$ & $\begin{array}{l}-0.0989 \\
(0.0848)\end{array}$ & $\begin{array}{l}-0.0017 \\
(0.1266)\end{array}$ \\
\hline Floor & $\begin{array}{c}\mathbf{0 . 1 1 7 7} \\
(0.0619)\end{array}$ & $\begin{array}{c}0.1282 \\
(0.0806)\end{array}$ & $\begin{array}{c}0.0483 \\
(0.0446)\end{array}$ & $\begin{array}{c}0.0936 \\
(0.0868)\end{array}$ & $\begin{array}{c}\mathbf{0 . 1 9 5 0} \\
(0.1000)\end{array}$ & $\begin{array}{c}0.1654 \\
(0.2399)\end{array}$ \\
\hline Age of building & $\begin{array}{c}0.0652 \\
(0.0514)\end{array}$ & $\begin{array}{c}0.1196 \\
(0.0776)\end{array}$ & $\begin{array}{c}0.0473 \\
(0.0570)\end{array}$ & $\begin{array}{c}0.0707 \\
(0.0671)\end{array}$ & $\begin{array}{c}\mathbf{0 . 1 5 4 3} \\
(0.0587)\end{array}$ & $\begin{array}{l}-0.0050 \\
(0.0805)\end{array}$ \\
\hline \multicolumn{7}{|l|}{ Macroeconomic characteristics } \\
\hline Mortgage burden (\%) & $\begin{array}{c}\mathbf{0 . 6 5 9 7} \\
(0.2365)\end{array}$ & $\begin{array}{c}0.3141 \\
(0.4046)\end{array}$ & $\begin{array}{c}0.2857 \\
(0.3028)\end{array}$ & $\begin{array}{c}0.7649 \\
(0.2808)\end{array}$ & $\begin{array}{c}\mathbf{0 . 8 9 2 3} \\
(0.2502)\end{array}$ & $\begin{array}{c}0.7630 \\
(0.5157)\end{array}$ \\
\hline Rental index (\%) & $\begin{array}{l}\mathbf{1 2 . 3 6 6 6} \\
(4.2082) \\
\end{array}$ & $\begin{array}{c}8.6868 \\
(7.2572)\end{array}$ & $\begin{array}{c}2.7196 \\
(7.0681)\end{array}$ & $\begin{array}{l}\mathbf{1 0 . 1 0 8 1} \\
(5.9773)\end{array}$ & $\begin{array}{l}\mathbf{1 2 . 2 8 0 4} \\
(4.9172)\end{array}$ & $\begin{array}{c}\mathbf{2 1 . 7 0 8 1} \\
(10.6611)\end{array}$ \\
\hline Possible turnover index (\%) & $\begin{array}{c}0.3118 \\
(0.2113) \\
\end{array}$ & $\begin{array}{c}\mathbf{0 . 8 2 0 3} \\
(0.2904) \\
\end{array}$ & $\begin{array}{c}\mathbf{0 . 7 6 1 0} \\
(0.2436)\end{array}$ & $\begin{array}{c}0.4783 \\
(0.2785) \\
\end{array}$ & $\begin{array}{c}0.2849 \\
(0.2642) \\
\end{array}$ & $\begin{array}{l}-0.1483 \\
(0.3542)\end{array}$ \\
\hline Economic growth rate (\%) & $\begin{array}{c}0.0011 \\
(0.0017)\end{array}$ & $\begin{array}{c}0.0010 \\
(0.0039)\end{array}$ & $\begin{array}{c}0.0022 \\
(0.0020)\end{array}$ & $\begin{array}{c}0.0014 \\
(0.0021)\end{array}$ & $\begin{array}{c}0.0011 \\
(0.0026)\end{array}$ & $\begin{array}{l}-0.0003 \\
(0.0059)\end{array}$ \\
\hline Mortgage rate $(\%)$ & $\begin{array}{l}-0.0733 \\
(0.0561)\end{array}$ & $\begin{array}{l}-\mathbf{0 . 1 7 4 9} \\
(0.0794)\end{array}$ & $\begin{array}{l}-\mathbf{0 . 1 1 5 1} \\
(0.0524)\end{array}$ & $\begin{array}{l}-0.0217 \\
(0.0593)\end{array}$ & $\begin{array}{l}-0.0283 \\
(0.0773)\end{array}$ & $\begin{array}{l}-0.1398 \\
(0.1286)\end{array}$ \\
\hline Inflation rate $(\%)$ & $\begin{array}{c}1.1354 \\
(1.2455) \\
\end{array}$ & $\begin{array}{c}3.2774 \\
(1.3135) \\
\end{array}$ & $\begin{array}{c}3.1248 \\
(1.0503)\end{array}$ & $\begin{array}{c}0.8004 \\
(1.4658) \\
\end{array}$ & $\begin{array}{l}-0.1500 \\
(1.6646) \\
\end{array}$ & $\begin{array}{c}1.7712 \\
(2.9077) \\
\end{array}$ \\
\hline M1B money supply growth rate (\%) & $\begin{array}{c}0.0003 \\
(0.0069)\end{array}$ & $\begin{array}{l}-0.0041 \\
(0.0088) \\
\end{array}$ & $\begin{array}{l}-0.0046 \\
(0.0059)\end{array}$ & $\begin{array}{c}0.0021 \\
(0.0080)\end{array}$ & $\begin{array}{c}0.0110 \\
(0.0086)\end{array}$ & $\begin{array}{c}0.0060 \\
(0.0115)\end{array}$ \\
\hline \multicolumn{7}{|l|}{ Housing policy } \\
\hline Luxury tax & $\begin{array}{l}-\mathbf{0 . 0 7 6 2} \\
(0.0396)\end{array}$ & $\begin{array}{l}-0.0892 \\
(0.1150)\end{array}$ & $\begin{array}{l}-0.0334 \\
(0.0697)\end{array}$ & $\begin{array}{l}-0.0533 \\
(0.0638)\end{array}$ & $\begin{array}{l}-0.0454 \\
(0.0592)\end{array}$ & $\begin{array}{l}-0.0317 \\
(0.1017)\end{array}$ \\
\hline Actual pricing registration & $\begin{array}{l}-\mathbf{0 . 0 8 3 6} \\
(0.0442)\end{array}$ & $\begin{array}{l}-\mathbf{0 . 1 4 0 4} \\
(0.0716)\end{array}$ & $\begin{array}{l}-0.0789 \\
(0.0500)\end{array}$ & $\begin{array}{l}-0.1209 \\
(0.0448)\end{array}$ & $\begin{array}{l}-0.1045 \\
(0.0362)\end{array}$ & $\begin{array}{l}-\mathbf{0 . 2 1 5 7} \\
(0.0917)\end{array}$ \\
\hline$R$-squared/Pseudo- $R^{2}$ & 0.9438 & 0.8294 & 0.8381 & 0.8001 & 0.7305 & 0.7114 \\
\hline Adjusted- $R^{2}$ & 0.9323 & 0.7947 & 0.8051 & 0.7594 & 0.6757 & 0.6527 \\
\hline Durbin-Watson stat & 1.8470 & & & & & \\
\hline
\end{tabular}

Tables 6-11 show that the mortgage rate had a negative influence on housing prices in Taipei City and all administrative districts. In the quantile regression model, the impact was the most significant in houses of low and medium prices. Under the continuing policy of low mortgage rates and taxation policies for residential housing without any complementary measure, housing prices in Taiwan would continue to rise, which further proved that the majority of buyers of houses with low and medium prices would indeed consider the mortgage rate more favorably. The study found that the average unit area price (considering the cases with significant coefficient value) could be reduced by $5 \%$ to $18 \%$ when the mortgage rate was up-regulated by $1 \%$. Under the current low mortgage rate, any increase would affect the disposable income available for the purchase of a house. In terms of supply and demand in the real estate market, only an increase in mortgage rates would reduce the willingness to purchase a house. And, if the supply of housing were maintained while the demand decreased, housing prices could drop, serving as a solution to the problem in Taipei City.

Information transparency due to the actual pricing registration showed a negative influence on house prices in Taipei City and all administrative districts and the overall effect was profound. After the actual pricing registration was implemented, the house prices in Taipei City and all districts were reduced by $4 \%$ to $29 \%$ (considering the cases with significant coefficient value). It was known that information transparency could correct the overall actual transaction prices to avoid the earning of inappropriate commission by intermediary agencies, which could further affect the house prices. Information transparency could guide the buyer in judgment of the market and avoid erroneous 
information, which could raise the house price. The policy of luxury tax was originally intended by the government to reduce house prices. However, interestingly, the results showed an influence on houses with high prices, while the rest was not affected by it. Therefore, in the real estate market, the luxury tax was easily transferred to buyers and had no significant impact on house prices.

\subsection{The Empirical Result of Individual Building Characteristics as Influential Factors on Housing Prices for the Cheapest and Most Expensive Group of Houses in Taipei}

So far, the analysis samples of the averages of individual transaction data further diluted the influence of these housing characteristics on house prices. To further understand, in-depth, the significance of housing characteristics on the overall housing prices, in terms of unit price, Table 4 classified the unit area price into four categories: below 300 thousand, 301-500 thousand, 501-700 thousand, 701-900 thousand and above 900 thousand. In cases of housing with unit price below 300 thousand, these cases accounted for $14 \%$ of the total sample and the actual number of houses was 12,275 . Housing with prices at more than 910 thousand accounted for $6 \%$ of the total sample and the actual number of houses was 5123. This study specifically analyzed individual transaction information and variables in these two groups to examine the importance of influence on house prices by each housing characteristic.

Table 12 shows the empirical result of individual building characteristics as influential factors on house prices in each administrative district of Taipei City. The empirical investigation of Table 12 is based on the specification of Equation (4-2). As shown in the category of below 300 thousand in the first column of Table 12, with the exception of regions of high unit prices (including Sinyi, Daan, and Chungcheng districts) as unaffected, there were 297 records of housing with unit price below 300 thousand, constituting approximately $2.4 \%$ of all cases in the Sinyi district, which were mostly high in price. Other administrative regions were also significantly influenced, but negative in correlation. For the Shihlin district, the house prices were generally 3.86\% lower than that of the Neihu district. In the aspect of building type, only the suite apartment had a significantly lower unit price than the villa, approximately by $18.83 \%$. Others, such as the high-rise apartment, the mansion, the apartment, the suite apartment, and the townhouse, were all lower than the villa in pricing, but without statistical significance. In terms of housing policy, the implementation of the luxury tax and the actual pricing registration could significantly affect housing of low prices, and such influence by the luxury tax was instead in a positive direction. Once the policy of luxury tax was implemented, the unit price of housing with low price in Taipei City was slightly increased by $1.85 \%$. The actual pricing registration had the opposite and negative effect. Since the system implementation, the unit price of housing with low price in Taipei City dropped by as much as $17.78 \%$, nearly 10 times the effect seen by the policy of luxury tax.

The right column in Table 12 shows the empirical result of housing with unit area price of above 900 thousand. In terms of influence on housing of high price by building characteristics, only the floor number showed significantly negative influence. It was possibly due to its location, which presented the best economic value for store front that the first floor had higher unit price. The building area, the age of the building, and the parking space had no effect on house prices, even at some good locations. The empirical result of factors affecting house prices in Taipei City showed significant impact, in addition to the Sinyi district, the Daan district, and the Chungcheng district, in which these cases were mostly concentrated as housing with high price in the northern district. In the Daan district, the house prices were $25.9 \%$ higher than that of the Neihu district, while the Chungcheng district and the Sinyi district were also higher by $9.55 \%$ and $10.95 \%$, respectively. For the type of building, with the exception of townhouse, which was not significantly different from villas, others, such as the high-rise apartment, the mansion, the apartment, and the suite apartment were all lower than the villa in pricing. For example, a high-rise apartment would have a lower price by $48.38 \%$ than that of a villa. In the housing policy, the implemented luxury tax and registration system had, respectively, positive and negative impacts on houses with low prices by $8.45 \%$ for the luxury tax and 
$6.76 \%$ for the actual pricing registration. When compared to housings of low unit price, the negative influence by the actual pricing registration on housings of high unit price was less profound.

Table 12. The empirical result of individual building characteristics as influential factors on housing prices for the cheapest and most expensive group of houses in Taipei.

\begin{tabular}{|c|c|c|c|c|}
\hline \multirow{2}{*}{ Housing Prices (Unit Price) } & \multicolumn{2}{|c|}{ TWD 300 Thousand Per Ping and Below } & \multicolumn{2}{|c|}{ TWD 900 Thousand Per Ping and Above } \\
\hline & Coefficient & $p$-Value & Coefficient & $p$-Value \\
\hline c & 3.4181 & 0.1031 & 5.2805 & 0.1478 \\
\hline Log (building area) & -0.0166 & 0.0040 & -0.0014 & 0.0048 \\
\hline Floor & 0.0018 & 0.0007 & -0.0052 & 0.0009 \\
\hline Age of building & 0.0007 & 0.0002 & 0.0001 & 0.0003 \\
\hline Parking space & -0.0064 & 0.0032 & 0.0011 & 0.0136 \\
\hline Chungcheng district & -0.0050 & 0.0129 & 0.0955 & 0.0236 \\
\hline Sinyi district & 0.0107 & 0.0128 & 0.1095 & 0.0245 \\
\hline Nangang district & -0.0203 & 0.0099 & 0.0094 & 0.0460 \\
\hline Shihlin district & -0.0386 & 0.0080 & 0.0565 & 0.0277 \\
\hline Daan district & 0.0032 & 0.0158 & 0.2590 & 0.0346 \\
\hline Chungshan district & -0.0168 & 0.0087 & 0.0594 & 0.0244 \\
\hline Songshan district & -0.0346 & 0.0137 & 0.0773 & 0.0245 \\
\hline Wanhua district & -0.0651 & 0.0073 & -0.0312 & 0.0250 \\
\hline Wenshan district & -0.0001 & 0.0064 & -0.0246 & 0.0450 \\
\hline Tatung district & -0.0415 & 0.0098 & 0.0372 & 0.0376 \\
\hline Beitou district & -0.0367 & 0.0067 & -0.0377 & 0.0395 \\
\hline High-rise building & -0.1549 & 0.1010 & -0.4838 & 0.1410 \\
\hline Mansion & -0.1631 & 0.1010 & -0.5142 & 0.1409 \\
\hline Apartment & -0.1631 & 0.1010 & -0.4721 & 0.1407 \\
\hline Condo & -0.1883 & 0.1014 & -0.4720 & 0.1413 \\
\hline Townhouse & -0.1472 & 0.1031 & -0.1760 & 0.1410 \\
\hline Luxury tax & 0.0185 & 0.0099 & 0.0845 & 0.0330 \\
\hline Actual pricing registration & -0.1778 & 0.0074 & -0.0676 & 0.0120 \\
\hline R-squared & \multicolumn{2}{|c|}{0.1198} & \multicolumn{2}{|c|}{0.1682} \\
\hline Adjusted- $\mathrm{R}^{2}$ & \multicolumn{2}{|c|}{0.1182} & \multicolumn{2}{|c|}{0.1646} \\
\hline F-statistic & \multicolumn{2}{|c|}{75.833} & \multicolumn{2}{|c|}{46.959} \\
\hline Durbin-Watson stat & \multicolumn{2}{|c|}{1.5820} & \multicolumn{2}{|c|}{1.7147} \\
\hline
\end{tabular}

Red characters indicate significance on $p$-value $<0.05$. The administrative area was set 0 in the Neihu area, and 1 otherwise. "High-rise building", "Mansion", "Apartment", "Condo", and "Townhouse" are set as dummy variables representing the building type of each transaction target. The housing type was set 0 for the villa, and 1 otherwise. The luxury tax and actual pricing registration were dummy variables for the implementation time of each policy. The observations for house prices in each TWD 300 thousand and below was 12,275; TWD 900 thousand and above 5132.

From the conclusions of the empirical results, it was found that housing characteristics as variables had a much more significant effect on houses of low unit price than of high unit price. In terms of housing policy, the implementation of the luxury tax showed significant influence on houses of both low and high unit price, proving a transfer of such tax to the buyers. The actual pricing registration had a profoundly negative impact on both low and high unit price because of information transparency, which allowed the buyers to carefully select based on market value.

\section{Conclusions}

The houses in the Taipei metropolitan area are expensive and only a few buyers are able to afford the purchase. Therefore, many buyers must devote time and effort in the search for real estate information in order to find and purchase the most affordable housing at the most reasonable price. Therefore, analysis of the influential factors of housing prices could assist buyers in understanding housing values. The objective was to understand whether housing policy could curb pricing and the importance of macroeconomic factors on these prices. It also looked at the similarities and differences of the effects of different housing policies and the macroeconomic factors on the submarket pricing in real estate.

In this study, the housing prices in Taipei City were analyzed by the regression of the monthly average pricing and the influential factors, as well as the cross-sectional information of individual housing prices of the highest and the lowest groups. The former focused on the relationship between 
the overall average house price and the overall variables (including government policies), while the latter emphasized the impact of individual housing characteristics and different administrative districts on housing prices. The empirical data contained the analysis of information from more than 80,000 housing transactions from June 2008 to May 2014. It showed that information transparency and the raising of mortgage rates were the most important factors when it came to curbing housing prices. House price regulation is a complicated issue which will affect the capital market, the financial market, and even the macroeconomics, and must be explored with caution. Generally, the raising of mortgage rates as the housing policy can lead to a chain reaction and not a single measure is effective by itself. Perhaps, policy makers should think about whether "the environment of Taiwan's financial market has fulfilled the conditions to justify raising mortgage rates" or "consider how to create an environment in the financial market that will allow for the increase in mortgage rates".

The empirical analysis of this study showed that in terms of the factors influencing housing prices in the Taipei metropolitan area, the regulations should include policies that can control the mortgage rates and the actual pricing registration. Low mortgage rates would affect speculative investors and drive up the market price. Thus, it was recommended that the raising of mortgage rates could suppress housing prices. Transparency in real estate information has always been a very important factor in transactions and could help to avoid the raising of prices by an intermediary agency or the third party for extra benefit from transaction discrepancies due to unclear pricing information. Both parties of a transaction must have the complete information to determine the most appropriate pricing for purchase to improve the real estate market and achieve the ideal of home ownership. In terms of housing policy, the luxury tax could not curb housing prices, but instead allowed transfer of the tax to the buyers or reduced the willingness for sales due to higher added-value taxes, resulting in a lock-in effect in the real estate market. The actual pricing registration allowed information transparency to reduce speculative investment to drive up the market price. It was imperative to keep information transparent to allow both parties to make the most appropriate judgment in transactions. The long-term implementation of such a policy could benefit the taxation income for the government, achieving a win-win situation for all parties. Therefore, the actual pricing registration was an important government policy in solving the problem of high housing prices in the metropolitan area and in improving the domestic real estate market toward housing veracity.

Author Contributions: Chien-Ming Yu and Pei-Fen Chen conceived and designed the ideas. Chien-Ming and collected the data and estimated the models. Chien-Ming and Pei-Fen analyzed the data and discussed the empirical results. Chien-Ming and Pei-Fen revised the paper.

Conflicts of Interest: The authors declare no conflict of interest.

\section{References}

1. Zhang, L.; Zoli, E. Leaning against the Wind: Macroprudential Policy in Asia; IMF Working Paper 14/22; International Monetary Fund: Washington, DC, USA, 2014.

2. Levin, E.J.; Pryce, G.B.J. A statistical explanation for extreme bids in the house market. Urban Stud. 2007, 44, 2339-2355. [CrossRef]

3. Reichert, A.K. The impact of interest rates, income and employment upon regional housing prices. J. Real Estate Financ. Econ. 1990, 3, 373-391. [CrossRef]

4. Muellbauer, J. When is a Housing Market Overheated Enough to Threaten Stability? In Property Markets and Financial Stability Reserve Bank of Australia; Heath, A., Packer, F., Windsor, C., Eds.; Reserve Bank of Australia: Sydney, Australia, 2012.

5. Chang, Y.-W.; Chang, C.-O. Developing, assessment and integration of the exist and presale housing price indexes-The case of Taipei City. J. Hous. Stud. 2009, 2, 13-34.

6. Peng, C.W.; Chang, C.-O. The Impact of Expectation and Preannouncement Effect on Real Estate Cycles in Taiwan. J. Manag. Stud. 2000, 17, 343-368.

7. Chang, C.-O.; Liu, H.-L. Real estate quality, price and consumer price index on discussion. Chung-Hua Inst. Econ. Res. 1993, 12, 12-28. 
8. Lin, C.-C.; Hwang, P.L. A study on the relationship between housing price and macro-Economic variable. J. Taiwan Land Econ. 1995, 71, 143-160.

9. Wu, S.-T. Income, money and house prices: An observation of Taipei Area for the past two decades. J. Hous. Stud. 1994, 2, 49-66.

10. Li, H.-C.; Chang, C.-O. The relationship between floor area and unit price across different residential types in Taipei Metropolitan Area. J. Taiwan Land Res. 2006, 9, 63-87.

11. Lee, C.-F.; Chang, C.-O. An empirical study on the housing price in Kaohsiung City. J. Hous. Stud. 2014, 22, 72-89.

12. Lin, C.-C.; Ma, Y.-C. An application of mass appraisal and the hedonic equation in the real estate market in Taiwan. J. Hous. Stud. 2007, 16, 1-22.

13. Chang, Y.-W.; Chang, C.-O. Quantile regression analysis of residential mass appraisal models-improvement in atypical housing appraisal. J. City Plan. 2009, 36, 281-304.

14. Shieh, W.S. The Tax Effects for Tenure Choice of Housing in Taiwan. J. Hous. Stud. 2000, 9, 153.

15. Yang, H.-C. Real Estate Investment and Market Analysis; Wensheng Book Co: Taipei, Taiwan, 2001; pp. $223-232$.

16. Chang, T.-C. A study of the impact of political business cycles on housing prices. J. Taiwan Land Econ. 2001, 12, 179-204.

17. Summers, L.H. Inflation, the Stock Market, and Owner-occupied Housing. Am. Econ. Rev. 1981, 71, $429-434$.

18. International Monetary Fund. Global Financial Stability Report, Chapter 3: Housing Finance and Financial Stability; International Monetary Fund: Washington, DC, USA, 2011.

19. Lane, P.R. International Capital Flows and Domestic Credit Conditions, Macroeconomic Review; Monetary Authority of Singapore, Economic Policy Group: Singapore, Singapore, 2014.

20. Rey, H. Dilemma not trilemma: The global financial cycle and monetary policy independence. In Economic Policy Symposium; Hole, J., Ed.; Federal Reserve Bank of Kansas City: Kansas City, MO, USA, 2013.

21. Hofmann, B.; Bogdanova, B. Taylor rules and monetary policy: A global 'Great Deviation'? BIS Quarterly Review. Available online: https:/ / ssrn.com/abstract=2206331. (accessed on 20 March 2018).

22. Taylor, J. Housing and Monetary Policy, Housing. In Housing Finance and Monetary Policy; Symposium, J.H., Ed.; Federal Reserve Bank of Kansas City: Kansas City, MO, USA, 2007; pp. 463-476.

23. Bernanke, B.S. The Global Saving Glut and the U.S. Current Account Deficit, Speech Delivered at the Sandridge Lecture; Virginia Association of Economists: Richmond, VA, USA, 2005.

24. Favilukis, J.; Ludvigson, S.C.; van Nieuwerbrugh, S. The Macroeconomic Effects of Housing Wealth, Housing Finance, and Limited Risk-Sharing in General Equilibrium; Working Paper, NYU; University of Chicago Press: Chicago, IL, USA, 2013.

25. Glaeser, E.L.; Gottlieb, J.D.; Gyourko, J. Can Cheap Credit Explain the Housing Boom?; NBER Working Paper, No. 16230; July 2010. Available online: http:/ / www.nber.org/chapters/c12622 (accessed on 20 March 2018).

26. Del Giudice, V.; De Paola, P.; Manganelli, B.; Forte, F. The monetary evaluation of environmental externalities through the analysis of real estate prices. Sustainability 2017, 9, 229. [CrossRef]

27. Peng, C.-W.; Chang, C.-O. An analysis of structural changes in housing prices: Cases of Taipei City and Taipei. J. Taiwan Land Res. 2004, 7, 27-46.

28. Chen, J.-Y.; Chou, M.-L.; Tsai, I.-C.; Chen, M.-C. Price, income and interest rate elasticity of demand for housing. J. Hous. Stud. 2014, 23, 17-32.

29. Gatzlaff, D.H.; Tirtiroglu, D. Real Estate Market Efficiency: Issues and Evidence. J. Real Estate Lit. 1995, 3, 157-189.

30. Lancaster, K. The theory of qualitative linear systems. Econometrica 1965, 33, 395-409. [CrossRef]

31. Rosen, S. Hedonic prices and implicit markets: Product differentiation in pure competition. J. Political Econ. 1974, 82, 34-55. [CrossRef]

32. Miller, N.G. Residential property hedonic pricing models: A review. Res. Real Estate 1982, 2, 31-56.

33. Kirby, A. Computer assisted mass appraisal: The Queensland experience. In Computer Assisted Mass Appraisal: An International Review; McCluskey, W.J., Adair, A.S., Eds.; Ashgate Limited: Hants, UK, 1997; pp. 198-209.

34. Mark, G.; Goldberg, M.A. Multiple regression analysis and mass assessment: A review of the issues. Apprais. J. 1998, 56, 89-110.

35. Detweiler, J.H.; Radigan, R.E. Computer assisted real estate appraisal: A tool for the practicing appraiser. Apprais. J. 1999, 67, 280-286. 
36. Su, W.-C.; Liu, T.-J.; Huang, F.; Chen, F.-Y. Using Hedonic Pricing Approach to Analyze the Factors Influencing Housing Price. Land Issues Res. Q. 2013, 12, 55-68.

37. Koenker, R.; Bassett, G.W. Robust tests for heteroscedasticity based on regression quantiles. J. Deriv. 1982, 50, 43-62. [CrossRef]

38. Koenker, R.; Hallock, K.F. Quantile Regression: An Introduction; Econometrics at the University of Illinois, 2000. Available online: http:/ / www.econ.uiuc.edu/ roger/research/intro/html (accessed on 5 October 2006).

39. Kuan, C.M. An Introduction to Quantile Regression; Lecture Notes; Institute of Economics, Academia Sinica: Taipei, Taiwan, 2003; Available online: http:/ / www.sinica.edu.tw/ ckuan. (accessed on 5 October 2006).

40. Koenker, R.; Bassett, G.W. Regression quantiles. Econometrica 1978, 46, 211-244. [CrossRef]

41. Chuang, C.-C.; Kuan, C.-M. A quantile regression analysis of return-volume relation: Evidence from the Taiwan and U.S. Institute of Economics. Regres. Acad. Econ. Pap. 2005, 33, 379-404.

42. Liao, C.-J.; Chang, C.-O. Asymmetric price effects of residential real estate brokerage service using quantile regressions. City Plan. 2006, 33, 1-16.

43. Chen, C.-L. Counterfactual decomposition of public-private sector wage differentials in Taiwan: Evidence from quantile. Regres. Acad. Econ. Pap. 2007, 35, 473-520.

44. Lee, J.-S. A study of the factor of Taiwan IPO: Quantile regression. Rev. Secur. Futur. Mark. 2008, 20, 47-100.

45. Sirmans, G.S.; Macpherson, D.A.; Zietz, E.N. The composition of hedonic pricing models. J. Real Estate Lit. 2005, 13, 3-44.

46. Del Giudice, V.; De Paola, P.; Manganelli, B.; Forte, F. Real estate appraisals with Bayesian approach and Markov Chain Hybrid Monte Carlo Method: An. application to a central urban area of Naples. Sustainability 2017, 9, 2138. [CrossRef]

47. Del Giudice, V.; Manganelli, B.; De Paola, P. Hedonic analysis of housing sales prices with semiparametric methods. Int. J. Agric. Environ. Inf. Syst. 2017, 8, 65-77. [CrossRef]

48. Chen, M.-C. The Determination of House Prices in Taiwan: Long-Run Equilibrium and Short-Run Dynamics. Unpublished Master's Thesis, Graduate School of Land Economy, Cambridge University, Cambridge, UK, 1998.

49. Chang, C.-O. A Study of House Price Index in Taiwan Area; The Council of Economic Planning and Development: Taipei, Taiwan, 1995.

(C) 2018 by the authors. Licensee MDPI, Basel, Switzerland. This article is an open access article distributed under the terms and conditions of the Creative Commons Attribution (CC BY) license (http:// creativecommons.org/licenses/by/4.0/). 